Journal of Food Technology Research

2022 Vol. 9, No. 1, pp. 18-45.

$\operatorname{ISSN}(e): 2312-3796$

$\operatorname{ISSN}(p): 2312-6426$

DOI: $10.18488 /$ fftr.v9i1.2927

(C) 2022 Conscientia Beam. All Rights Reserved.

check for
updates

\title{
WHEY FORTIFIED READY-TO-RECONSTITUTE ELEPHANT APPLE (DILLENIA INDICA) JUICE POWDER: METHODICAL OPTIMIZATION, MICRO-STRUCTURAL AND IN VITRO DIGESTION ANALYSES
}

(iD) Udangshree Borah
(i) Rimki Boruah ${ }^{2}$
(i) Sahijul Islam ${ }^{3}$
(i) Abhijit Borah ${ }^{4}$
(i) Ananta Saikia ${ }^{5}$
(D) Robin Boro
(i) Hemanta Saikia ${ }^{7}$
(D) Srikanth Mutnuri
(i) Anasuya Ganguly
(i) Rinku Baishya
(i) Lakshi Saikia

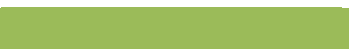

\section{Article History}

Received: 28 December 202 Revised: 31 January 2022 Accepted: 14 February 2022 Published: 18 February 2022

\section{Keywords}

\section{Whey}

Elephant apple

Microparticulate powder

In vitro digestion

Response surface methodology Ready-to-reconstitute beverage.

\author{
${ }_{1,0,5,10}^{10}$ Department of Horticulture (Food Science and Technology Programme), Assam Agricultural University, \\ Jorhat, Assam, India. \\ 'Email: udangshree02@gmail.com \\ 'Email:rimboruah58@gmail.com \\ ${ }^{5}$ Email:ananta.saikia@aau.ac.in \\ "Email:manashi.das@aau.ac.in \\ ${ }^{3}$ Department of Food Engineering and Technology, Tezpur University, Assam, India. \\ ${ }^{s}$ Email:sahijul.aus@gmail.com \\ ${ }^{4}$ Department of Agricultural Engineering, Assam Agricultural University, Jorhat, Assam, India. \\ ${ }^{*}$ Email:abhijit.borah@aau.ac.in \\ ${ }^{6}$ Department of Agricultural Biotechnology, Assam Agricultural University, Jorhat, Assam, India. \\ ${ }^{6}$ Email: robin.boro@aau.ac.in \\ ${ }^{7}$ College of Sericulture, Titabar, Assam Agricultural University, Jorhat, Assam, India. \\ Email:hemanta.saikia@aau.ac.in \\ ${ }^{8.9}$ Department of Biological Sciences, Birla Institute of Technology and Sciences, Pilani, Goa, India. \\ ${ }^{8}$ Email:srikanth.mutnuri@gmail.com \\ ${ }^{\circ}$ Email: ganguly@goa.bits-pilani.ac.in \\ ${ }^{10}$ Chemical Sciences and Technology Division, CSIR-North East Institute of Science and Technology \\ (NEIST), Assam, India. \\ ${ }^{10}$ Email:rinku.niper@gmail.com \\ ${ }^{\prime \prime}$ Department of Material Science, CSIR-North East Institute of Science and Technology (NEIST), Assam, \\ India. \\ "Email:l.saikia@gmail.com \\ (+ Corresponding author)
}

\section{ABSTRACT}

Elephant apple fruit, though bestowed with multifarious medicinal properties and available in many Asian countries, has no known commercial processed product due to its tough fibrous calyces, highly astringent juice and brown discolouration. In this study, the juice was blended with concentrated whey in different proportions (v/v) for assessing organoleptic acceptability. Principal Component Analysis of the sensory scores and subsequent evaluation of blends' antioxidant activity revealed the superiority of $1: 1(\mathrm{v} / \mathrm{v})$ admixture over other counterparts. Further, study focussed on optimization of process variables (maltodextrin concentration and inlet temperature of spray dryer) for recuperating beverage powder from the juice-whey blend $(1: 1 \mathrm{v} / \mathrm{v})$. Developed powders presented different surface morphologies (wrinkled/shrunk/ellipsoidal/fused particles having 2-30 $\mu \mathrm{m}$ diameters), and were organoleptically favourable with good yield (63.33$88.33 \%)$, dispersibility (33.40-56.57\%), moderate antioxidative potential (37.45-54.57\%), improved sugar, protein and whiteness index. In-vitro digestion release of protein and antioxidant activity from the optimized powder showed increasing trend with time, unlike those of fresh juice and juice-whey blend $(1: 1 \mathrm{v} / \mathrm{v})$. Thus, ready-to-reconstitute juice powder(s) with appreciable features was developed from an underutilized fruit using methodical statistical approaches, and the resultant product was found to provide protracted release of protein and antioxidants during simulated digestion. 
Contribution/Originality: Dillenia indica based products are not available commercially till date; in this study, juice processed into a convenient reconstitutable form without affecting much of its bioactive compounds is a "firstof-its-kind" example. Amalgamation of whey masked the astringency of pristine Dillenia indica juice; aiding in value added functional drink.

\section{INTRODUCTION}

Dillenia indica, commonly known as Elephant apple, is an underutilized minor wild fruit, growing abundantly in India, Bangladesh, Nepal, Sri Lanka, China, Indonesia, Vietnam, Thailand, Myanmar and Malaysia. The fruits are large ovoid consisting of imbricate sepals enveloping numerous seeds embedded in a mucilaginous core. Lately, there has been a growing interest for this fruit owing to its several biological activities such as antidiabetic, antioxidative, anti-inflammatory, antimicrobial and wound healing property (Migliato et al., 2011). However, the mature fruits are very astringent to sour in taste, highly fibrous with cumbersome processing and the juice turns dark brown soon after extraction. As such, the fruit is used sporadically in culinary preparation (Abdille, Singh, Jayaprakasha, \& Jena, 2005), with no known commercially available processed product reported till date. For balancing out the undesirable astringency, Saikia and Saikia (2002) processed the fruit juice into squash and evaluated its quality changes during storage. In light of the burgeoning attention to functional drinks, it seems prudent to blend the juice with a weak or bland flavoured ingredient possessing other positive attributes. In this milieu, whey, a byproduct of the cheese industry, has been popularly incorporated with different fruits and vegetables, adding nutritional value to conventional juices (Bazaria \& Kumar, 2016; Uscategui, Velásquez, \& Valencia, 2018). Unfortunately, literature pertaining to blending of Dillenia indica juice/pulp with dairy or non-dairy ingredients is currently lacking.

Seasonal availability of Dillenia indica fruit creates another bottleneck in its processing. Though Nayak, Basumatary, Chandrasekar, Seth, and Kesavan (2020) determined the effect of thermo-sonication and high pressure processing on quality attributes of the pristine juice, the shelf-life was established as 60 days only at $4{ }^{\circ} \mathrm{C}$. To ensure its availability throughout the year and also to the large sector of urban population even in far-flung areas, production of quality juice powder is a pressing need. Among the drying technologies, spray drying has successfully produced low-cost quality powders from juice and extract of various plants; however, spray dried powders have an inherent sticky nature, owing to the presence of low molecular weight sugars and acids of juice, which is often mitigated by incorporating high molecular weight drying adjunct or carrier agents like gums, maltodextrin (MD), protein, etc. In the same sense, being an excellent source of protein, whey is reported to form protective layer around sugary mass (Shi, Fang, \& Bhandari, 2013), thermo-labile bioactive components (Bernard, Regnault, Gendreau, Charbonneau, \& Relkin, 2011; Uscategui et al., 2018), and aids in higher product recovery during spray drying (Bhusari, Muzaffar, \& Kumar, 2014). For the development of a new product, it is imperative to methodically standardize the blending or formulation, so that an integral balance that translates into an excellent quality and good acceptability can be achieved. This often necessitates the application of multivariate statistical tools like Principal Component Analysis (PCA), Partial Least Square regression, Artificial Neural Networks, etc., which helps in reducing the data set and prioritizing the factors responsible for sample segregation and selection. Following the work of Mwove, Gogo, Chikamai, Omwamba, and Mahungu (2018) and Puri, Khamrui, Khetra, Malhotra, and Devraja (2016) PCA biplot was adopted in this study for sensory characterization of juice-whey mix, which was subsequently used for spray drying. Again, the quality of spray dried powders is influenced by a wide variety of controllable and uncontrollable factors (inlet air temperature; aspiration; feed flow rate; concentration and nature of carrier agent used; dry matter content, glass transition temperature and viscosity of the feed; relative humidity of the incoming air; etc.), and optimizing these process parameters is crucial for achieving the best output possible. The present investigation, therefore, aims to explore the possibility of developing a nutritious ready-to-reconstitute beverage powder from Dillenia indica juice-whey mix having optimum techno-functional properties, using Response Surface Methodology (RSM). 


\section{MATERIALS AND METHODS}

\subsection{Materials}

Mature fruits of Dillenia indica were procured from horticulture orchard located within latitude and longitude of $26^{\circ} 72^{\prime} \mathrm{N}$ and $94^{\circ} 20^{\prime} \mathrm{E}$, respectively (Deshmukh, Okram, Angami, Rymbai, \& Jha, 2019) and fresh whey were purchased from local market. MD of 12 dextrose equivalent (DE) and all the reagents were purchased from HiMedia ${ }^{\circledR}$.

\subsection{Extraction of Dillenia Indica Juice}

Physical morphology of the fruit is analysed and discussed in Supplementary Table S1. Calyces of the fruit were separated manually, washed and cut into small pieces of 1-1.5 cm thickness and the inner mucilaginous core was discarded. These pieces were then ground in a kitchen grinder (Havells, Momenta NV 750, India) using deionised water in a ratio of $1: 10(\mathrm{w} / \mathrm{v})$, filtered through muslin cloth to obtain a clear juice of $2 \%$ total solids.

Table S1. Physical parameters of Dillenia indica fruit.

\begin{tabular}{l|c}
\hline Physical properties & Experimental values \\
\hline Length $(\mathrm{mm})$ & $108.4 \pm 1.27$ \\
\hline Width $(\mathrm{mm})$ & $96.5 \pm 3.19$ \\
\hline Thickness $(\mathrm{mm})$ & $90.4 \pm 1.99$ \\
\hline Weight $(\mathrm{g})$ & $628 \pm 2.63$ \\
\hline Volume $\left(\mathrm{cm}^{3}\right)$ & $528.9 \pm 2.18$ \\
\hline Geometric mean diameter $(\mathrm{mm})$ & $119.5 \pm 3.01$ \\
\hline Surface Area $\left(\mathrm{mm}^{2}\right)$ & $37598.9 \pm 2.71$ \\
\hline Sphericity index $(\%)$ & $1.15 \pm 1.4$ \\
\hline Aspect ratio & $103.2 \pm 1.18$ \\
\hline Density $\left(\mathrm{g} / \mathrm{cm}^{3}\right)$ & $1.43 \pm 1.75$ \\
\hline Note: Values=Mean $\pm \mathrm{SD}(\mathrm{N}=10)$. &
\end{tabular}

\subsection{Pre-Treatment of Whey}

Procured whey of $5.23 \pm 0.82$ total solids and $\mathrm{pH} 4.06 \pm 0.58$, was immediately pasteurized at $90^{\circ} \mathrm{C}$ for $5 \mathrm{~min}(\mathrm{Lim}$, Benner, \& Clark, 2019), followed by concentrating it in a rotary vacuum evaporator (IKA ${ }^{\circledR}$ RV 10 digital, Germany) till the attainment of $30 \%$ total solids (hereafter referred to as 'concentrated whey').

\subsection{Formulation of Dillenia Indica Juice-Whey Blends and their Sensory Evaluation}

Pristine juice of Dillenia indica and concentrated whey were blended according to the formulations mentioned in Table 1, and were subjected to sensory evaluation using 9-point Hedonic scale, wherein $1=$ disliked extremely, $5=$ neither like nor dislike and $9=$ liked extremely were denoted.

Table 1. Formulation of blends using Dillenia indica juice and concentrated whey

\begin{tabular}{c|c|c}
\hline Code & Dillenia indica juice & Concentrated whey \\
\hline $\mathrm{T} 1$ & 100 & 0 \\
\hline $\mathrm{T} 2$ & 90 & 10 \\
\hline $\mathrm{T} 3$ & 80 & 20 \\
\hline $\mathrm{T} 4$ & 70 & 30 \\
\hline $\mathrm{T} 5$ & 60 & 40 \\
\hline $\mathrm{T} 6$ & 50 & 50 \\
\hline $\mathrm{T} 7$ & 40 & 60 \\
\hline $\mathrm{T} 8$ & 30 & 70 \\
\hline $\mathrm{T} 9$ & 20 & 80 \\
\hline $\mathrm{T} 10$ & 10 & 90 \\
\hline $\mathrm{T} 11$ & 0 & 100 \\
\hline
\end{tabular}


The samples were coded randomly in uniform containers and were presented to 20 semi-trained panelists to rate their sensory parameters, namely, appearance, colour, aroma, taste, flavour and overall acceptance (Pal, Khan, \& Mohanty, 2008). Sensory scores of the blends were evaluated by PCA in XLSTAT software (version 22.5.1052.0, Addinsoft, New York, USA). A biplot was constructed to help discriminate the samples based on their spatial distribution across few Principal Components (PCs) (Das Purkayastha et al., 2012). Antioxidant activity was determined using 2,2-diphenyl-1-picrylhydrazyl (DPPH) radical scavenging assay, as described by Vani, Rajani, Sarkar, and Shishoo (2008).

\subsection{Response Surface Methodology (RSM)}

RSM was adopted to optimize the process conditions for obtaining reconstitutable beverage powder from Dillenia indica juice-whey blend, using a lab-scale spray dryer (LSD-48 Mini Spray Dryer, JISL, India), wherein the aspiration (air flow) and feed flow rate were kept constant at $45 \%$ and $20 \%$, respectively. Prior to the operation, total solid of feed was set at 20\%, and pH was adjusted within 3.8-4.5 (Park, Bastian, Farkas, \& Drake, 2014). Inlet air temperature of the dryer (A) and MD concentration as drying adjunct (B) were taken as independent variables for the optimization of four response/dependent variables (powder yield (\%), dispersibility (\%), antioxidant activity (\%) and organoleptic acceptability). The Central Composite Design (CCD) was applied using Design-Expert ${ }^{\circledR}$ software (Version 11.0.1.0, Stat-Ease Inc., Minneapolis, USA), which generated 13 experimental runs at $\alpha= \pm 1.414$ with 5 center points and 3 levels of each variables set as 120,140 and $160^{\circ} \mathrm{C}$ of inlet air temperature, and $5 \%, 15 \%$ and $25 \%$ of MD Table 2 . Analysis of variance (ANOVA) was performed on the experimental data and a difference of $p \leq 0.05$ between the experimental and predicted data was considered statistically significant. Experimental data for the selected responses were fitted into second order polynomial Equation 1 and were optimized by Desirability function Equation 2. High values of coefficient of determination $\left(\mathrm{R}^{2}>0.90\right)$ indicate good fit between the observed and predicted values. Nonsignificant $(\mathrm{p}>0.05)$ lack of fit implies that the model is good and fit for prediction.

$$
Y_{k}=\beta_{k 0}+\sum_{i=1}^{n} \beta_{k i} x_{i}+\sum_{i=1}^{n} \beta_{k i i} x_{i}^{2}+\sum_{i=1}^{n-1} \sum_{j=i+1}^{n} \beta_{k i j} x_{i} x_{j}+e_{k}
$$

where, $\Upsilon_{k}=$ response variable.

$\beta_{k 0}=$ Coefficient of fitted response at center point.

$\beta_{k i}=$ linear coefficient.

$\beta_{k i i}=$ quadratic coefficient.

$\beta_{k j}=$ interaction coefficient.

$x=$ independent variable.

$e_{k}=$ error

$$
D=\left(d_{1}^{r_{1}} \times d_{2}^{r_{2}} \times d_{3}^{r_{3}} \times d_{4}^{r_{4}}\right)^{\frac{1}{\left(r_{1}+r_{2}+r_{3}+r_{4}\right)}}
$$

where, $d_{i}=$ desirability index for $i^{\text {th }}$ responses

$r_{i}=$ relative importance.

\subsection{Physicochemical Parameters}

Prior to analysis, reconstitution of spray dried powder was performed by dispersing in distilled water at a ratio of $1: 10 \mathrm{w} / \mathrm{v}$ (Chau, Wang, \& Wen, 2007), while the fresh juice and whey were used as-is. Sensory evaluation was done by 9 -point Hedonic scale in same manner as described earlier. Viscosity was measured at $25^{\circ} \mathrm{C}$ using $\mathrm{Fungilab}$ viscometer (VISCO BASIC Plus L, Spain), attached with L2 spindle at $100 \mathrm{rpm}$ and expressed in centiPoise (cP). The $\mathrm{pH}$ was recorded by a digital $\mathrm{pH}$ meter (Eutech Instruments, Singapore). Titratable acidity and moisture content (MC) were determined by AOAC standard methods (AOAC, 2000). Total soluble solid (TSS) was measured by a digital refractometer (MA871 model, ATACO, Tokyo). Yield of powder was calculated using Equation 3 (Sulieman, 2014). 


$$
\text { Yield }(\%)=\frac{\text { weight of powder }(\mathrm{g})}{\text { solid content of the feed }(\%)} \times 100
$$

Solubility was determined according to the method described by Chau et al. (2007), and Equation 4 was used to calculate the percent solubility. Sample was reconstituted as mentioned earlier, stirred for $1 \mathrm{~h}$ at room temperature $\left(25^{\circ} \mathrm{C}\right)$ and centrifuged at $1500 \mathrm{rpm}$ for $10 \mathrm{~min}$. The supernatant was dried and weighed.

$$
\text { Solubility }(\%)=\frac{\text { weight of supernatant after drying }(\mathrm{g})}{\text { weight of sample }(\mathrm{g})} \times 100
$$

Dispersibility was determined by the method proposed by Aliakbarian, Casazza, Nani, and Perego (2017). Equation 5 was employed to calculate the percent dispersibility. Sample was reconstituted in water at a ratio of 1:10 $(\mathrm{w} / \mathrm{v})$, and stirred manually for $1 \mathrm{~min}$ at room temperature. The suspension was then allowed to stand undisturbed for $30 \mathrm{~min}$, followed by weighing $50 \mathrm{ml}$ of the aliquot.

where, $\mathrm{M}_{2}=$ Weight of $50 \mathrm{ml}$ of aliquot ( $\mathrm{g}$ ).

$$
\text { Dispersibility }(\%)=2 \times \frac{M_{2}(g)-M_{1}(g)}{M_{0}(g)} \times 100
$$

$\mathrm{M}_{1}=$ Weight of $50 \mathrm{ml}$ of distilled water $(\mathrm{g})$.

$\mathrm{M}_{0}=$ Weight of sample $(\mathrm{g})$.

Hygroscopicity of powder was determined by the method explained by Cai and Corke (2000) with minor modifications. Sample $(0.5 \mathrm{~g})$ in a pre-weighed dish was placed in a desiccator having $75 \pm 1 \%$ relative humidity (RH) and a temperature of $30{ }^{\circ} \mathrm{C}$. During the equilibration, $\mathrm{RH}$ and temperature inside the desiccators was constantly maintained and monitored by a digital RH clock (103-CTH, HTC ${ }^{\text {TM }}$, China). After 15 days, the sample was re-weighed and the hygroscopicity was expressed as $\mathrm{g}$ of moisture absorbed per $100 \mathrm{~g}$ dry solids.

Bulk density and tap density were determined according to the methodology of Dantas, Pasquali, CavalcantiMata, Duarte, and Lisboa (2018) and Equation 6 \& 7 were used for its calculation. Powder was poured into a graduated measuring cylinder and the volume occupied was recorded. Similarly, for tap density, the same sample in the measuring cylinder was tapped until no difference was noticed in the scale of the cylinder.

$$
\begin{aligned}
& \text { Bulk density }(\rho \mathrm{b})=\frac{\text { Sample mass }(\mathrm{g})}{\text { Apparent volume of sample }(\mathrm{ml})} \\
& \text { Tap density }(\rho \mathrm{gap})=\frac{\text { Sample mass }(\mathrm{g})}{\text { Tap volume of sample }(\mathrm{ml})}
\end{aligned}
$$

Flowability and cohesiveness of the powder were deduced from Carr index (CI) and Hausner ratio (HR), respectively Equations 8 \& 9. Supplementary Tables S2 and S3 show the specifications for CI and HR corresponding to their flowability and cohesiveness (Jinapong, Suphantharika, \& Jamnong, 2008; Sidlagatta, Venkata, Rao, Daniel, \& Lakshmipathy, 2020).

$$
\begin{gathered}
\mathrm{CI}=\frac{(\rho \operatorname{tap})-(\rho \mathrm{b})}{(\rho \operatorname{tap})} \times 100 \\
\mathrm{HR}=\frac{(\rho \operatorname{tap})}{(\rho \mathrm{b})}
\end{gathered}
$$

Table S2. Specification for Hausner ratio.

\begin{tabular}{l|c}
\hline Hausner ratio & Cohesiveness \\
\hline$<1.2$ & Low \\
\hline $1.2-1.4$ & Intermediate \\
\hline$>1.4$ & High \\
\hline
\end{tabular}

Total sugars was estimated by phenol-sulphuric acid method as described by Jain, Karibasappa, Dodamani, and Mali (2017). Total soluble protein was estimated by Lowry method (AOAC, 2000). Micro-Kjeldahl method was 
used to determine the total nitrogen content, which was then multiplied by a factor of 6.25 to derive crude protein (AOAC, 2000). Ash (total mineral) content was determined as per the procedure of AOAC (2000). Folin-Ciocalteu reagent assay was employed to determine the total phenol content (TPC) (Singleton \& Rossi, 1965; Soong \& Barlow, 2004). The total flavonoids content (TFC) was determined following the protocol of Kamtekar, Keer, and Patil (2014).

Table S3. Specification for Carr index.

\begin{tabular}{l|c}
\hline Carr Index (\%) & Flowability \\
\hline$<15$ & Very good \\
\hline $15-20$ & Good \\
\hline $20-30$ & Fair \\
\hline $35-45$ & Bad \\
\hline$>45$ & Very bad \\
\hline
\end{tabular}

Whiteness index (WI) was measured by the means of weighted ordinate method, using an ELISA microplate reader $\left(\right.$ BioTek $^{\circledR}$ Instruments EPOCH $2 \mathrm{NS}$, USA). The colour parameters L', a', b' were calculated (Equations 10, 11, 12) from the transmission spectra between 380 to $760 \mathrm{~nm}$ with $10 \mathrm{~nm}$ interval, and the recorded readings were converted to XYZ tristimulus values (Saikia, 1999). WI was deduced using Equation 13 (Pathare, Opara, \& Al-Said, 2013).

$$
\begin{gathered}
\mathrm{L}^{\prime}=10 \sqrt{Y} \\
\mathrm{a}^{\prime}=175\left(\frac{1.02 \mathrm{X}}{\mathrm{Y}}-1\right) \\
\mathrm{b}^{\prime}=70\left(1-\frac{0.847 Z}{Y}\right) \\
\mathrm{WI}=\sqrt{\left(100-L^{\prime 2}\right)+a^{\prime 2}+b^{\prime 2}}
\end{gathered}
$$

\subsection{Scanning Electron Microscopy (SEM)}

Surface morphology of the spray dried powder was observed under a field emission scanning electron microscope (FESEM) (Carl ZEISS Microscopy, Germany). Prior to the observation, the particles were mounted on carbon stubs fixed with double sided adhesive tape, followed by coating with a thin layer of gold under at an accelerating voltage of $5 \mathrm{kV}$ (Both, Boom, \& Schutyser, 2020).

\subsection{In-Vitro Digestion}

Digestibility of the juice, concentrated whey, juice:whey blend (T6) and reconstituted optimized powder were evaluated using a simulated gastric and intestinal fluid models (Chen, Li, \& Tang, 2015; Chen, Liu, \& Tang, 2020). Individual sample solution $(10 \mathrm{ml})$ was added to $0.1 \mathrm{M} \mathrm{HCl}$ while adjusting the $\mathrm{pH}$ to 1.5 , followed by pre-incubation for $10 \mathrm{~min}$. For simulating the gastric digestion, $10 \mathrm{mg}$ of pepsin powder was added and incubated at $37^{\circ} \mathrm{C}$ for $1 \mathrm{~h}$. Next, $250 \mathrm{mg}$ of bile extract powder was mixed along with the adjustment of $\mathrm{pH}$ to 7.0 with $4 \mathrm{M} \mathrm{NaOH}$ and incubated for another $10 \mathrm{~min}$. Finally, to simulate intestinal digestion, $20 \mathrm{mg}$ of pancreatin powder was added to the gastric chyme. Finally, digesta $(1 \mathrm{ml})$ were collected after 60, 90, $120 \mathrm{~min}$ of intestinal digestion, centrifuged at 10,000 rpm for $30 \mathrm{~min}$ at $4{ }^{\circ} \mathrm{C}$, and the supernatant was extracted twice with $95 \%$ ethyl acetate $(5 \mathrm{ml})$ to inactivate the enzymes. An aliquot of $500 \mu \mathrm{l}$ was sampled for estimation of liberated soluble protein and antioxidant activity, following the methods explained before.

\subsection{Statistical Analysis}

ANOVA using Tukey's honest significant difference (HSD) test was performed in SPSS software (version 16.0, IBM $^{\circledR}$ SPSS Statistics, Chicago) and considered significantly different among the samples at $95 \%$ confidence interval. Number of replicates taken for each analysis was 3, except for the physical parameters wherein 10 repetitions were performed. 


\section{RESULTS AND DISCUSSION}

\subsection{Organoleptic Comparison of Dillenia Indica Juice-Whey Blends Using PCA}

Average sensory scores assigned to the various blends formulated as per Table 1, are shown in Supplementary Table S4; amongst which T1 and T11, having pristine Dillenia indica juice and concentrated whey, respectively, were rated the lowest score. This in-turn indicates that use of lone base ingredient (especially juice), cannot qualify as a satisfactory drink and requires blending with appropriate components.

Table S4. Sensory parameters rating of the juice-whey blends

\begin{tabular}{l|c|c|c|c|c|c}
\hline Code & Appearance & Colour & Taste & Aroma & Flavour & Overall acceptance \\
\hline T1 & $5.11 \pm 0.93^{\mathrm{ab}}$ & $4.89 \pm 1.36^{\mathrm{a}}$ & $5.22 \pm 1.30^{\mathrm{ab}}$ & $5.22 \pm 0.97^{\mathrm{a}}$ & $5.33 \pm 0.87^{\mathrm{ab}}$ & $5.44 \pm 1.01^{\mathrm{a}}$ \\
\hline $\mathrm{T} 2$ & $5.22 \pm 1.20^{\mathrm{ab}}$ & $5.33 \pm 0.87^{\mathrm{a}}$ & $5.33 \pm 1.00^{\mathrm{ab}}$ & $5.67 \pm 0.71^{\mathrm{a}}$ & $5.00 \pm 1.58^{\mathrm{ab}}$ & $5.67 \pm 1.22^{\mathrm{a}}$ \\
\hline $\mathrm{T} 3$ & $5.11 \pm 1.36^{\mathrm{a}}$ & $5.33 \pm 1.00^{\mathrm{a}}$ & $4.44 \pm 0.73^{\mathrm{ab}}$ & $5.44 \pm 1.42^{\mathrm{a}}$ & $5.11 \pm 0.60^{\mathrm{ab}}$ & $5.56 \pm 1.13^{\mathrm{a}}$ \\
\hline $\mathrm{T} 4$ & $5.78 \pm 0.97^{\mathrm{ab}}$ & $6.67 \pm 1.41^{\mathrm{a}}$ & $4.56 \pm 1.24^{\mathrm{ab}}$ & $5.00 \pm 0.87^{\mathrm{a}}$ & $5.11 \pm 0.93^{\mathrm{ab}}$ & $5.11 \pm 1.36^{\mathrm{a}}$ \\
\hline $\mathrm{T} 5$ & $5.89 \pm 1.36^{\mathrm{ab}}$ & $6.44 \pm 1.74^{\mathrm{a}}$ & $4.89 \pm 2.26^{\mathrm{ab}}$ & $4.33 \pm 2.00^{\mathrm{a}}$ & $4.56 \pm 2.01^{\mathrm{ab}}$ & $5.67 \pm 1.80^{\mathrm{a}}$ \\
\hline $\mathrm{T} 6$ & $7.11 \pm 1.05^{\mathrm{b}}$ & $6.78 \pm 1.20^{\mathrm{a}}$ & $6.22 \pm 1.09^{\mathrm{b}}$ & $6.00 \pm 0.87^{\mathrm{a}}$ & $5.89 \pm 1.17^{\mathrm{b}}$ & $6.33 \pm 1.22^{\mathrm{a}}$ \\
\hline $\mathrm{T} 7$ & $6.33 \pm 1.32^{\mathrm{ab}}$ & $6.67 \pm 0.71^{\mathrm{a}}$ & $5.67 \pm 0.87^{\mathrm{ab}}$ & $5.44 \pm 1.24^{\mathrm{a}}$ & $5.33 \pm 1.12^{\mathrm{ab}}$ & $6.11 \pm 1.17^{\mathrm{a}}$ \\
\hline $\mathrm{T} 8$ & $6.56 \pm 0.88^{\mathrm{ab}}$ & $6.22 \pm 1.20^{\mathrm{a}}$ & $5.22 \pm 1.30^{\mathrm{ab}}$ & $5.11 \pm 1.45^{\mathrm{a}}$ & $5.11 \pm 0.93^{\mathrm{ab}}$ & $5.78 \pm 1.39^{\mathrm{a}}$ \\
\hline T9 & $6.33 \pm 1.66^{\mathrm{ab}}$ & $5.78 \pm 1.72^{\mathrm{a}}$ & $5.56 \pm 1.24^{\mathrm{ab}}$ & $5.89 \pm 1.27^{\mathrm{a}}$ & $4.89 \pm 1.05^{\mathrm{ab}}$ & $5.33 \pm 1.32^{\mathrm{a}}$ \\
\hline T10 & $6.22 \pm 1.64^{\mathrm{ab}}$ & $5.44 \pm 2.13^{\mathrm{a}}$ & $4.00 \pm 1.22^{\mathrm{a}}$ & $4.67 \pm 1.41^{\mathrm{a}}$ & $4.33 \pm 1.00^{\mathrm{ab}}$ & $4.67 \pm 1.00^{\mathrm{a}}$ \\
\hline T11 & $5.89 \pm 1.45^{\mathrm{ab}}$ & $5.33 \pm 1.66^{\mathrm{a}}$ & $4.00 \pm 1.22^{\mathrm{a}}$ & $4.44 \pm 1.01^{\mathrm{a}}$ & $4.00 \pm 1.12^{\mathrm{a}}$ & $4.89 \pm 0.78^{\mathrm{a}}$ \\
\hline
\end{tabular}

So for establishing the most suitable formulation(s), a PCA biplot was constructed Figure 1. Among the six PCs, the first two, namely $\mathrm{PC} 1$ and $\mathrm{PC} 2$, could satisfactorily account for $84.38 \%$ of the total variability in the data set (62.17\% and $22.22 \%$, respectively), and both had Eigen values greater than 1.0 (Supplementary Table S5).

Table S5. Eigen value and contribution of the principal components (PCs).

\begin{tabular}{l|c|c|c|c|c|c}
\hline & PC1 & PC2 & PC3 & PC4 & PC5 & PC6 \\
\hline Eigen value & 3.730 & 1.333 & 0.485 & 0.250 & 0.120 & 0.081 \\
\hline Variability (\%) & 62.170 & 22.215 & 8.089 & 4.172 & 1.997 & 1.357 \\
\hline Cumulative \% & 62.170 & 84.385 & 92.474 & 96.646 & 98.643 & 100.00 \\
\hline
\end{tabular}

The vector representation using first two PCs in Figure 1 clearly depicts the clustering of T6, T7, T8 and T9 in the first and second quadrants, wherein the sensory attributes are either overlying with the variables or in the vicinity of the formulations having significant effect $(\mathrm{p}<0.05)$. The distinction between these formulations against the least acceptable ones was clearly visible as the points were well-dispersed within the biplot. Judging from PCA biplot, the samples T6, T7, T8 and T9 were found to have greater organoleptic acceptability than their counterparts, and were accordingly tested for their antioxidant potential (Supplementary Table S6). The blend T6 possessed highest radical scavenging value $(59.16 \pm 0.37 \%)$, which can be credited to the presence of higher fraction of polyphenol-rich Dillenia indica juice than T7, T8 and T9. As T6 was found to be superior over the pristine fruit juice, concentrated whey and other blended formulations, it was selected for further study.

Table S6. Antioxidant activity (\%) of the selected juice-whey blends.

\begin{tabular}{l|c|c|c|c}
\hline T6 (1:1) & T7 (2:3) & T8 (3:7) & T9 (1:4) & CD $_{0.05}$ \\
\hline $59.16 \pm 0.37$ & $55.37 \pm 0.15$ & $52.87 \pm 0.41$ & $47.82 \pm 0.66$ & 0.115 \\
\hline
\end{tabular}

\subsection{Spray Drying of T6: Optimization of Process Variables By RSM}

The blend T6, mixed with different concentration of MD, was spray dried at various inlet air temperatures as per CCD Table 2. These ranges of MD and inlet temperature were selected on the basis of preliminary trials. Low level of $\mathrm{MD}(<5 \%)$ and inlet temperature $\left(<120^{\circ} \mathrm{C}\right)$ resulted in poor yield, and hence, were not considered in the study. 
Likewise, very high concentration of $\mathrm{MD}(>25 \%)$ caused blocking of the spray atomizer and inlet temperature greater than $160^{\circ} \mathrm{C}$ resulted in severe loss of antioxidative compounds in the final product.

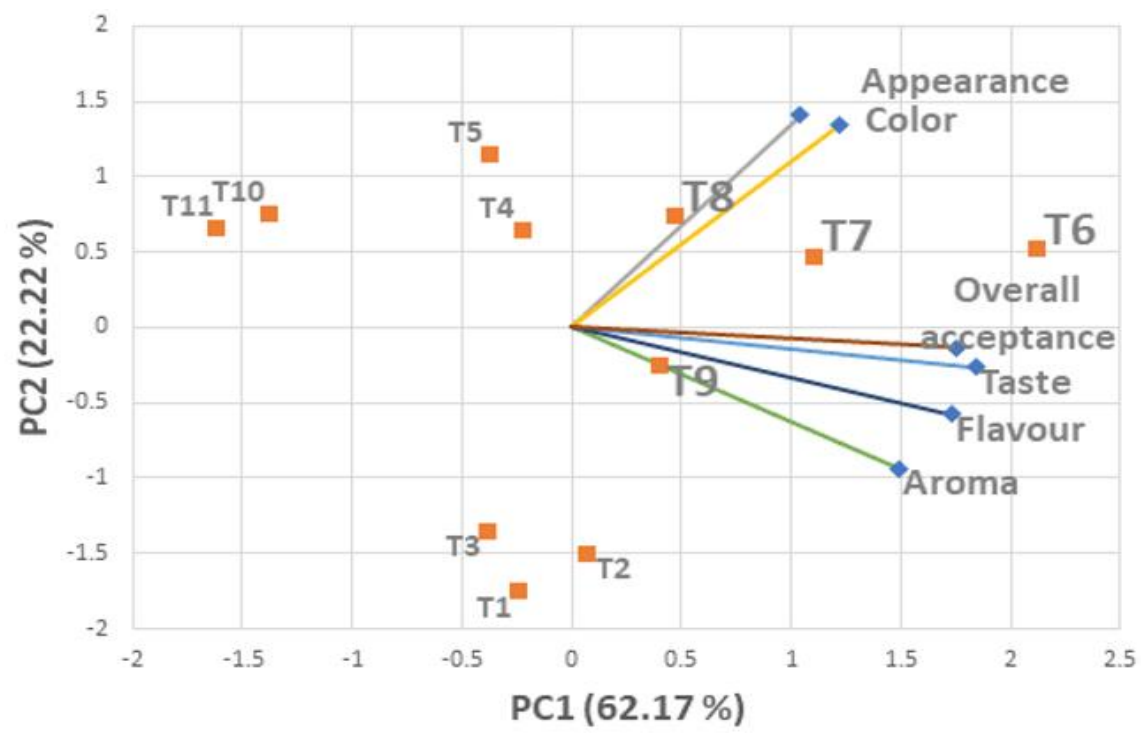

Figure 1. PCA biplot for the sensory ratings of Dillenia indica juice-whey blends.

Amongst the several determining factors, yield, dispersibility, antioxidant activity and organoleptic acceptability were chosen as the dependent variables for optimization because of their predominant dependency in regulating industrial output and marketability of the developed powder(s).

Table 2. Central composite design $(\mathrm{CCD})$ with experimental values of dependent variables.

\begin{tabular}{|c|c|c|c|c|c|c|}
\hline \multirow[t]{2}{*}{ Exp. Run } & \multicolumn{2}{|c|}{ Actual and coded values } & \multicolumn{4}{|c|}{ Response values } \\
\hline & $\begin{array}{c}\text { Inlet Temperature } \\
\left({ }^{\circ} \mathrm{C}\right)(\mathrm{A})\end{array}$ & $\begin{array}{c}\text { MD (\%) } \\
\text { (B) }\end{array}$ & Yield (\%) & $\begin{array}{c}\text { Dispersibility } \\
(\%)\end{array}$ & $\begin{array}{l}\text { Antioxidant } \\
\text { activity (\%) }\end{array}$ & $\begin{array}{l}\text { Organoleptic } \\
\text { acceptability }\end{array}$ \\
\hline 1 & 168.284 & 15 & $72.67 \pm 1.26^{\mathrm{d}}$ & $43.30 \pm 0.4 \mathrm{O}^{\mathrm{f}}$ & $47.56 \pm 0.28^{\mathrm{gh}}$ & $7.72 \pm 0.84^{\mathrm{f}}$ \\
\hline 2 & 140 & 15 & $83.00 \pm 2.00^{f}$ & $38.61 \pm 0.10^{\mathrm{d}}$ & $43.54 \pm 0.33^{\mathrm{d}}$ & $5.92 \pm 0.67^{\mathrm{bc}}$ \\
\hline 3 & 140 & 0.857864 & $67.67 \pm 1.53^{\mathrm{b}}$ & $38.97 \pm 0.31^{\mathrm{d}}$ & $42.87 \pm 0.24^{\mathrm{c}}$ & $4.00 \pm 0.97^{\mathrm{a}}$ \\
\hline 4 & 140 & 15 & $84.00 \pm 1.00^{f}$ & $34.51 \pm 0.03^{\mathrm{b}}$ & $44.18 \pm 0.43^{\mathrm{e}}$ & $6.01 \pm 0.75^{\mathrm{bc}}$ \\
\hline 5 & 140 & 15 & $85.67 \pm 0.58^{g}$ & $35.57 \pm 0.27^{\mathrm{c}}$ & $47.52 \pm 0.30^{\mathrm{g}}$ & $6.14 \pm 0.62^{b c}$ \\
\hline 6 & 111.716 & 15 & $71.50 \pm 1.00^{\mathrm{c}}$ & $33.40 \pm 0.44^{\mathrm{a}}$ & $53.58 \pm 0.37^{\mathrm{j}}$ & $6.35 \pm 0.55^{\mathrm{cd}}$ \\
\hline 7 & 120 & 25 & $72.33 \pm 2.52^{\mathrm{cd}}$ & $34.44 \pm 0.22^{\mathrm{b}}$ & $48.14 \pm 0.23^{\mathrm{hi}}$ & $6.84 \pm 1.7 \mathrm{O}^{\mathrm{de}}$ \\
\hline 8 & 140 & 15 & $88.33 \pm 1.53^{\mathrm{h}}$ & $38.51 \pm 0.25^{\mathrm{d}}$ & $48.32 \pm 0.45^{\mathrm{i}}$ & $5.82 \pm 0.93^{\mathrm{bc}}$ \\
\hline 9 & 140 & 15 & $83.67 \pm 1.15^{\mathrm{f}}$ & $35.44 \pm 0.27^{\mathrm{c}}$ & $45.49 \pm 0.41^{\mathrm{f}}$ & $5.82 \pm 0.93^{\mathrm{bc}}$ \\
\hline 10 & 160 & 25 & $77.00 \pm 2.65^{\mathrm{e}}$ & $56.57 \pm 0.25^{\mathrm{h}}$ & $37.45 \pm 0.46^{\mathrm{a}}$ & $8.16 \pm 0.97^{\mathrm{f}}$ \\
\hline 11 & 140 & 29.1421 & $86.67 \pm 0.58^{g}$ & $48.73 \pm 0.21^{\mathrm{g}}$ & $39.78 \pm 0.62^{\mathrm{b}}$ & $7.10 \pm 0.62^{\mathrm{e}}$ \\
\hline 12 & 120 & 5 & $63.33 \pm 2.08^{\mathrm{a}}$ & $33.47 \pm 0.11^{\mathrm{a}}$ & $54.58 \pm 0.42^{\mathrm{k}}$ & $5.69 \pm 0.98^{b}$ \\
\hline 13 & 160 & 5 & $76.67 \pm 1.53^{\mathrm{e}}$ & $40.44 \pm 0.16^{\mathrm{e}}$ & $47.55 \pm 0.33^{\mathrm{gh}}$ & $5.80 \pm 0.70^{\mathrm{bc}}$ \\
\hline
\end{tabular}

\subsubsection{Yield}

Yield of the powder at different temperatures and MD concentration are depicted in Table 2. The highest yield was recorded at $140^{\circ} \mathrm{C}$ of inlet temperature and $15 \% \mathrm{MD}$. The second order polynomial model for yield is given in Equation 14.

$$
\text { Yield }=84.00+3.73 \mathrm{~A}+4.32 \mathrm{~B}-2.67 \mathrm{AB}-4.03 \mathrm{~A}^{2}-4.99 \mathrm{~B}^{2}
$$

where, $\mathrm{A}=$ Inlet temperature

$\mathrm{B}=\mathrm{MD}$. 
Table S7. ANOVA showing the effects of independent variables as linear, interaction, and quadratic terms on the response variables.

\begin{tabular}{|c|c|c|c|c|c|c|c|c|c|c|c|c|c|c|c|c|c|}
\hline \multirow{2}{*}{ Source } & \multirow[b]{2}{*}{ df } & \multicolumn{4}{|c|}{ Yield } & \multicolumn{4}{|c|}{ Dispersibility } & \multicolumn{4}{|c|}{ Antioxidant activity } & \multicolumn{4}{|c|}{ Organoleptic acceptability } \\
\hline & & $\boldsymbol{\beta}$ & SS & F value & p-value & $\boldsymbol{\beta}$ & SS & F value & p-value & $\beta$ & SS & F value & p-value & $\beta$ & SS & F value & p-value \\
\hline Model & 5 & & 542.46 & 33.59 & $<0.0001$ & & 505.63 & 15.98 & 0.0010 & & 230.63 & 6.71 & 0.0134 & & 12.60 & 42.21 & $<0.0001$ \\
\hline A- Inlet Temp. & 1 & 3.73 & 111.06 & 34.38 & 0.0006 & 5.39 & 232.21 & 36.69 & 0.0005 & -3.28 & 86.04 & 12.51 & 0.0095 & 0.4209 & 1.42 & 23.75 & 0.0018 \\
\hline $\mathrm{B}-\mathrm{MD}$ & 1 & 4.32 & 149.15 & 46.18 & 0.0003 & 3.86 & 119.45 & 18.87 & 0.0034 & -2.61 & 54.60 & 7.94 & 0.0259 & 0.9868 & 7.79 & 130.5 & $<0.0001$ \\
\hline $\mathrm{AB}$ & 1 & -2.67 & 28.46 & 8.81 & 0.0209 & 3.79 & 57.51 & 9.09 & 0.0195 & -0.92 & 3.36 & 0.488 & $0.5074 *$ & 0.3025 & 0.366 & 6.13 & 0.0424 \\
\hline $\mathrm{A}^{2}$ & 1 & -4.03 & 112.94 & 34.97 & 0.0006 & 0.945 & 6.21 & 0.981 & $0.3550^{*}$ & 2.62 & 47.91 & 6.97 & 0.0335 & 0.6290 & 2.75 & 46.12 & 0.0003 \\
\hline $\mathrm{B}^{2}$ & 1 & -4.99 & 172.99 & 53.56 & 0.0002 & 3.69 & 94.96 & 15.00 & 0.0061 & -2.00 & 27.74 & 4.03 & $0.0846^{*}$ & -0.1135 & 0.089 & 1.50 & 0.2601 * \\
\hline Residual & 7 & & 22.61 & & & & 44.30 & & & & 48.14 & & & & 0.417 & & \\
\hline Lack of Fit & 3 & & 18.70 & 6.38 & $0.0527^{*}$ & & 29.88 & 2.76 & $0.1755^{*}$ & & 31.00 & 2.41 & $0.2073^{*}$ & & 0.346 & 6.37 & $0.0528^{*}$ \\
\hline Pure Error & 4 & & 3.91 & & & & 14.42 & & & & 17.14 & & & & 0.072 & & \\
\hline Corrected Total & 12 & & 565.07 & & & & 549.93 & & & & 278.7 & & & & 13.01 & & \\
\hline $\mathrm{R}^{2}$ & & 0.960 & & & & 0.919 & & & & 0.827 & & & & 0.9679 & & & \\
\hline Adjusted $\mathrm{R}^{2}$ & & 0.931 & & & & 0.862 & & & & 0.704 & & & & 0.9450 & & & \\
\hline Adeq Precision & & 16.16 & & & & 13.69 & & & & 9.865 & & & & 23.186 & & & \\
\hline $\mathrm{CV} \%$ & & 2.29 & & & & 6.39 & & & & 5.68 & & & & 3.90 & & & \\
\hline
\end{tabular}

Note: *Non-significant at $5 \%$ level, df: degree of freedom, $\beta$ : coefficients, SS: sum of squares. 
Linear, quadratic and interaction terms were found to have significant positive effect on the process yield $(\mathrm{p}<0.05)$ (Supplementary Table S7). MD concentration was found to have higher impact on yield $(\beta=4.32)$ than the inlet temperature ( $\beta=3.73$ ), as MD is known to improve the handling properties of spray dried products by acting as a bulking agent (Watson, Lea, \& Bett-Garber, 2017). Figure 2(A) shows the increase in yield with increasing inlet temperature and $\mathrm{MD}$ concentration. Higher temperature ensures faster drying rate for product formation. However, this trend was obliterated beyond $160^{\circ} \mathrm{C}$, when the sugars on particle surfaces might have been heated, causing them to stick to the wall of drying chamber (Telang \& Thorat, 2010; Wang, Dufour, \& Zhou, 2015), and thus reducing the powder yield.

\subsubsection{Dispersibility}

Dispersibility is a vital reconstitutional parameter, which allows the particles to separate (disperse) into individual entity on gentle mixing. Figure $2(\mathrm{~B})$ indicates the increase in dispersibility index with increasing inlet temperature and MD concentration, which is well demonstrated by significant effect of all the linear and interaction terms $(\mathrm{p}<0.05)$, along with the quadratic term of MD (Supplementary Table S7). The second order polynomial model for dispersibility is given in Equation 15.

$$
\text { Dispersibility }=36.53+5.39 \mathrm{~A}+3.86 \mathrm{~B}+3.79 \mathrm{AB}+0.9446 \mathrm{~A}^{2}+3.69 \mathrm{~B}^{2}
$$

where, $\mathrm{A}=$ Inlet temperature

$$
\mathrm{B}=\mathrm{MD}
$$

Low MC of the final product results in greater moisture gradient between the particles and surrounding water. Therefore, when dispersed in water, uptake of water is fast. This contributes to better reconstitution of the powder. Results were in accordance with Aliakbarian et al. (2017) and Giri Saroj, Mangaraj, Sinha Lalan, and Tripathi Manoj (2017), who developed powders from chocolate beverage and soy beverage, respectively.

\subsubsection{Antioxidant Activity}

Radical scavenging activity of the powders was in the range of $37.45 \%-54.57 \%$ Table 2. The polynomial equation for antioxidant activity of the spray dried powders is given below Equation 16.

Antioxidant activity $=45.81-3.28 \mathrm{~A}-2.61 \mathrm{~B}-0.9159 \mathrm{AB}+2.62 \mathrm{~A}^{2}-2.00 \mathrm{~B}^{2}$

where, $\mathrm{A}=$ Inlet temperature.

$$
\mathrm{B}=\mathrm{MD} \text {. }
$$

Figure 2(C) clearly depicts the decrease in antioxidant activity with increasing temperature and MD concentration, which could be linked to the degradation of heat-labile phenolics and flavonoids of the juice, and polypeptides of the whey (Saikia, Mahnot, \& Mahanta, 2015). Dilution effect by high quantity of MD in feed might also lead to reduced antioxidative capacity of powders (Mishra, Mishra, \& Mahanta, 2014). The linear terms as-wellas quadratic term of inlet temperature were found to have significant effect $(\mathrm{p}<0.05)$ on powders' antioxidative potential (Supplementary Table S7).

\subsubsection{Organoleptic Acceptability}

Sensory scores of the reconstituted beverage varied within 4-8.2 Table 2. Sample containing the lowest amount of MD $(0.86 \%$ and $5 \%)$ scored the lowest rating $(\geq 5)$, which could be attributed to the stickiness of the powder obtained at such low MD level; such powders fail to form uniform suspension during mixing, resulting in the formation of tiny agglomerates suspending in the reconstituted drink. This is in line with the observation of better dispersibility in presence of higher MD. The equation for organoleptic acceptability of the reconstituted beverage is given in Equation 17.

Organoleptic acceptability $=5.94+0.4209 \mathrm{~A}+0.9868 \mathrm{~B}+0.3025 \mathrm{AB}+0.6290 \mathrm{~A}^{2}-0.1135 \mathrm{~B}^{2}$

where, $\mathrm{A}=$ Inlet temperature.

$\mathrm{B}=\mathrm{MD}$. 
All linear and interaction terms, as-well-as quadratic term of inlet temperature of the polynomial equation were found to be significant $(\mathrm{p}<0.05)$ (Supplementary Table S7). The magnitude of the coefficient of the linear terms of MD evidently indicates its impact on the organoleptic acceptability of powders $(\beta=0.99)$. Likewise, Figure 2 (D) shows the rise in organoleptic scores with the increasing quantity of MD. This can be explained by the good dispersibility of powder in presence of MD, as stated earlier. Another reason could be possible masking of the astringent flavour of Dillenia indica juice by MD, which has often been reported to mask undesirable flavours and odours during spray drying (Abraham \& Mathew, 2013; Alayoubi et al., 2016; Bertelsen, Laursen, Knudsen, Møller, \& Kidmose, 2018).

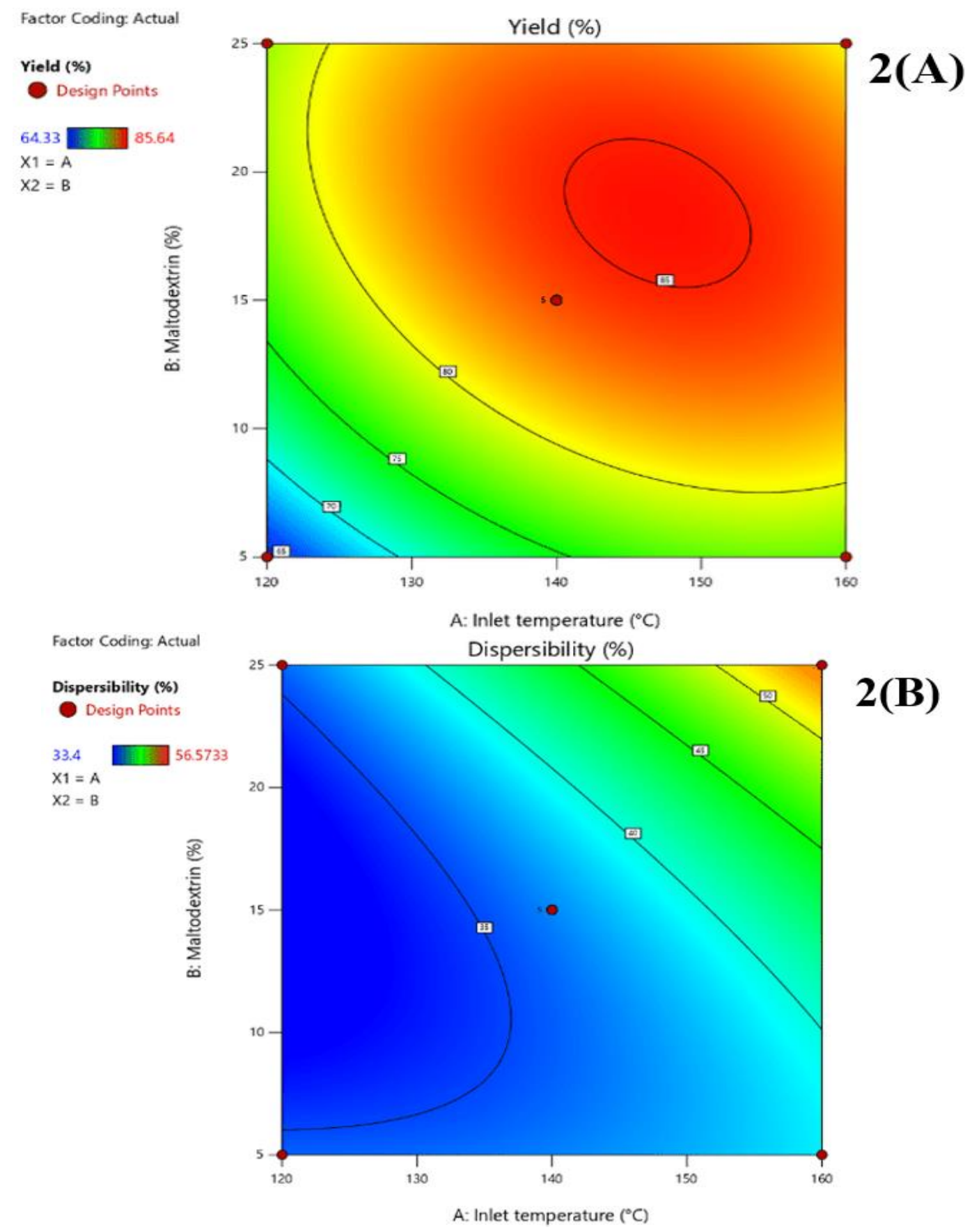



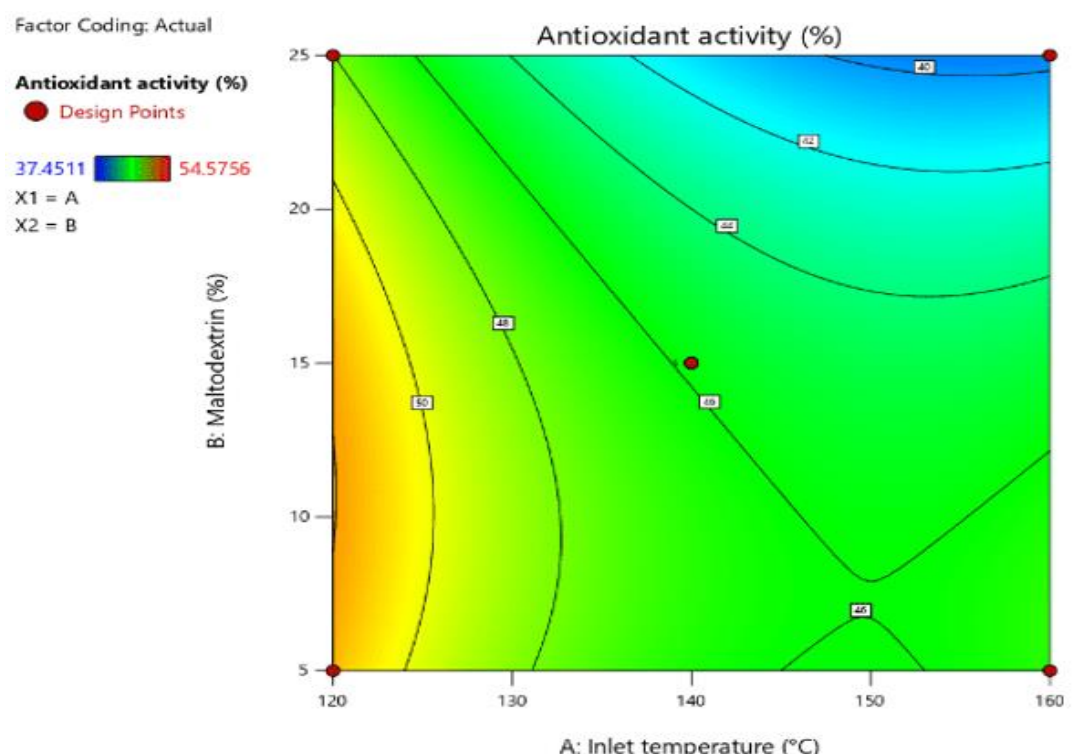

2(C)

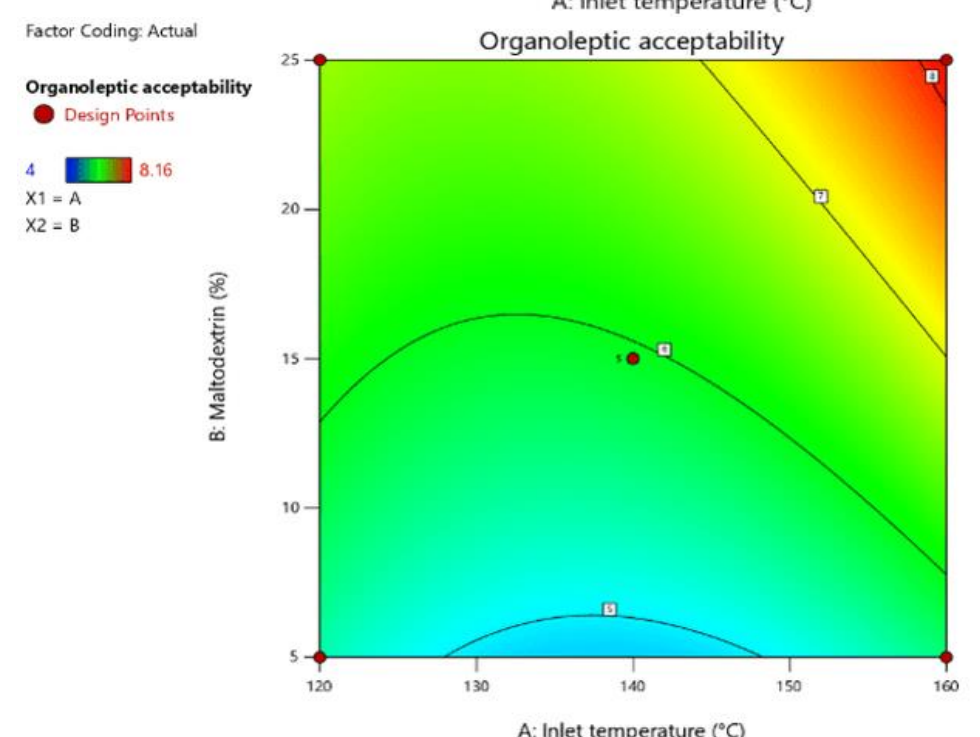

2(D)

Figure 2. Two-dimensional plots for the effects of process variables on (a) yield, (b) Dispersibility, (c) Antioxidant activity and (d) Organoleptic acceptability.

\subsection{Prediction of the Optimum Condition and its Validation}

The desired goals for independent variables were set within the range of experimental values, while the response parameters were chosen to maximize (Supplementary Table S8). The optimum values predicted for independent variables were $160^{\circ} \mathrm{C}$ of inlet air temperature and $19.727 \%$ MD (Supplementary Table S8). Experimental runs performed at the stated optimum condition were then used to verify the accuracy of the polynomial models. Table 3 vouches the fact that observed experimental values were reasonably close to the predicted values $(p>0.01)$, which inturn confirms the validity of the models for optimization.

Table S8. Optimum solution of process and response variables at desired goal and criteria.

\begin{tabular}{l|c|c|c|c|c}
\hline \multirow{2}{*}{ Parameters } & \multirow{2}{*}{ Desired Goal } & \multicolumn{2}{|c|}{ Criteria } & \multirow{2}{*}{ Pmportance } & \\
\cline { 3 - 5 } & & Lower limit & Upper limit & & \\
\hline Inlet temp. $\left({ }^{\circ} \mathrm{C}\right)$ & In range & 120 & 160 & 3 & 160 \\
\hline MD $(\%)$ & In range & 5 & 25 & 3 & 19.72 \\
\hline Yield (\%) & Maximize & 64.33 & 85.64 & 3 & 83.35 \\
\hline Dispersibility (\%) & Maximize & 33.4 & 56.57 & 3 & 47.30 \\
\hline Antioxidant activity (\%) & Maximize & 37.45 & 54.57 & 3 & 43.04 \\
\hline Organoleptic acceptability & Maximize & 4 & 8.16 & 3 & 7.58 \\
\hline
\end{tabular}


Table 3. Validation of the developed models and experimental values of the quality parameters of powder developed at predicted optimum condition.

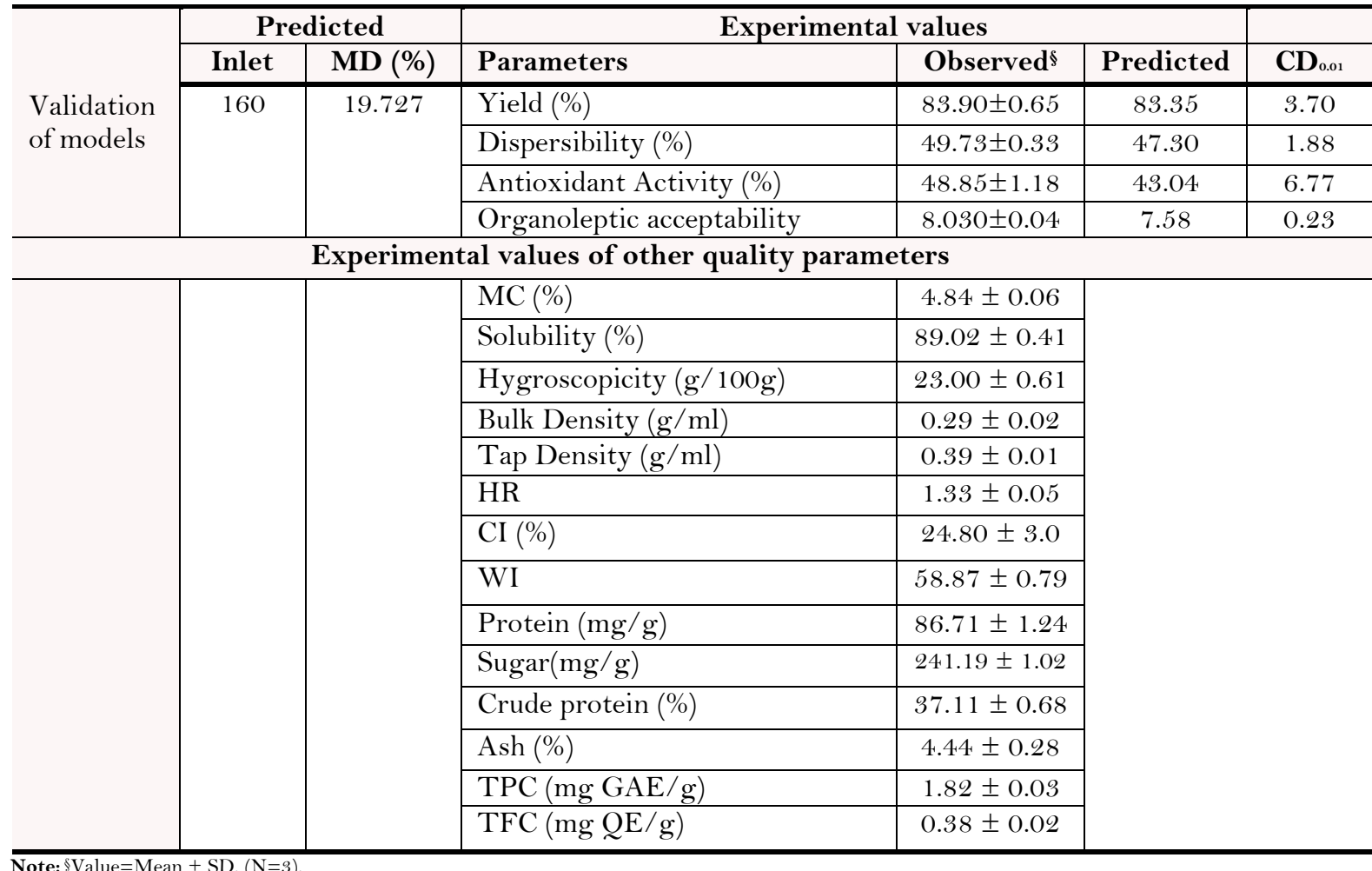

\subsection{Quality Attributes of the Powder Obtained at the Predicted Optimum Condition}

Physicochemical parameters of the powder obtained at the predicted optimum condition $\left(160^{\circ} \mathrm{C}\right.$ inlet temperature and $19.7 \% \mathrm{MD}$ ) are described in Table 3. Powders exhibited good solubility and dispersibility with intermediate hygroscopicity, and fair flowability. Its total soluble sugar decreased by $49.04 \%$ as compared to that of T6 (Supplementary Table S9). This decrease can be acribed to the probable formation of sugar-protein complex (Maillard browning) and degradation of free sugars during the drying process. Mitrović, Popović, Miletic, Leposavić, and Korićanac (2019) reported similar observation while drying plum fruits. Crude protein content and polyphenols of the optimized powder decreased by $38.41 \%$ and $98 \%$ respectively, when compared with those of the feed (T6) (Supplementary Table S9), probably due to thermal degradation of the heat labile proteins and polyphenols. Another reason for this reduction could be the interaction of sugars and polyphenols with the proteins (Papadopoulou \& Frazier, 2004; B. Wang, Tchessalov, Warne, \& Pikal, 2009). Despite of drastic reduction in phenolic content, the decrease in antioxidant activity of the optimized powder was only $17.42 \%$, with respect to that of T6, although both are expected to be in concurrence with each other.

Table S9. Physicochemical parameters of juice, concentrated whey and T6 blend.

\begin{tabular}{|c|c|c|c|c|c|c|c|c|}
\hline & $\begin{array}{c}\text { Viscosity } \\
\text { (cP) }\end{array}$ & $\mathrm{pH}$ & $\begin{array}{c}\text { Acidity } \\
(\mathrm{g} / 100 \mathrm{ml})\end{array}$ & $\begin{array}{c}\text { Total } \\
\text { sugar } \\
\text { (g/100g) }\end{array}$ & $\begin{array}{c}\text { Crude } \\
\text { protein } \\
(\%)\end{array}$ & $\begin{array}{c}\text { Soluble } \\
\text { protein } \\
(\mathrm{g} / \mathrm{100g})\end{array}$ & $\begin{array}{c}\text { TPC (g } \\
\text { GAE/ } 100 \\
g)\end{array}$ & $\begin{array}{l}\text { Antioxidant } \\
\text { activity (\%) }\end{array}$ \\
\hline Juice & $16.57 \pm 0.78$ & $3.71 \pm 0.95$ & $1.56 \pm 0.52 *$ & $53.0 \pm 0.25$ & $4.12 \pm 0.82$ & $1.95 \pm 0.81$ & $27.85 \pm 0.86$ & $64.0 \pm 0.59$ \\
\hline Whey & $6.20 \pm 0.98$ & $4.50 \pm 1.03$ & $0.50 \pm 0.79^{\$}$ & $5.02 \pm 0.46$ & $58.84 \pm 0.76$ & $24.05 \pm 0.69$ & $\mathrm{ND}^{\#}$ & $6.83 \pm 0.68$ \\
\hline $\begin{array}{c}\text { T6 } \\
\text { Blend }\end{array}$ & $11.2 \pm 1.7$ & $4.10 \pm 1.35$ & $1.74 \pm 0.82$ & $47.33 \pm 0.71$ & $60.25 \pm 1.87$ & $19.08 \pm 0.93$ & $11.45 \pm 0.66$ & $59.16 \pm 0.37$ \\
\hline
\end{tabular}

This anomaly can be construed from the antioxidative potential of the Maillard products formed between sugars and amino acids of protein at high temperature of spray dryer. Reconstituted beverage from optimized powder showed a WI of 58.87, which was better than that of the fresh juice (33.94), rendering better acceptability to oxidation prone 
Dillenia indica based products. Addition of whey and MD, thus, improved the colour of the beverage powder by masking the undesirable brown pigments of the fruit juice; the latter is otherwise besmirched for its dark-coloured astringent juice

\subsection{Other Physicochemical Parameters of Spray Dried Powders}

Apart from the above mentioned dependent variables, other parameters anticipated to impact the quality of the powder, as influenced by the independent variables, were also analyzed and discussed alongside Table 4. The graphical interpretation of these interactions can be viewed in Supplementary Figure S1.

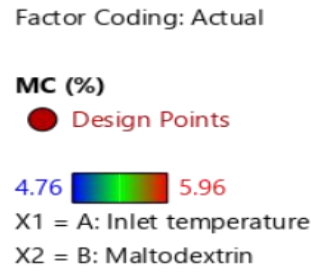

(A)

Factor Coding: Actual

\section{Solubility (\%)}

Design Points

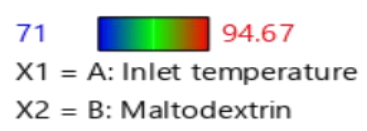

71

$\mathrm{X} 2$ = B: Maltodextrin
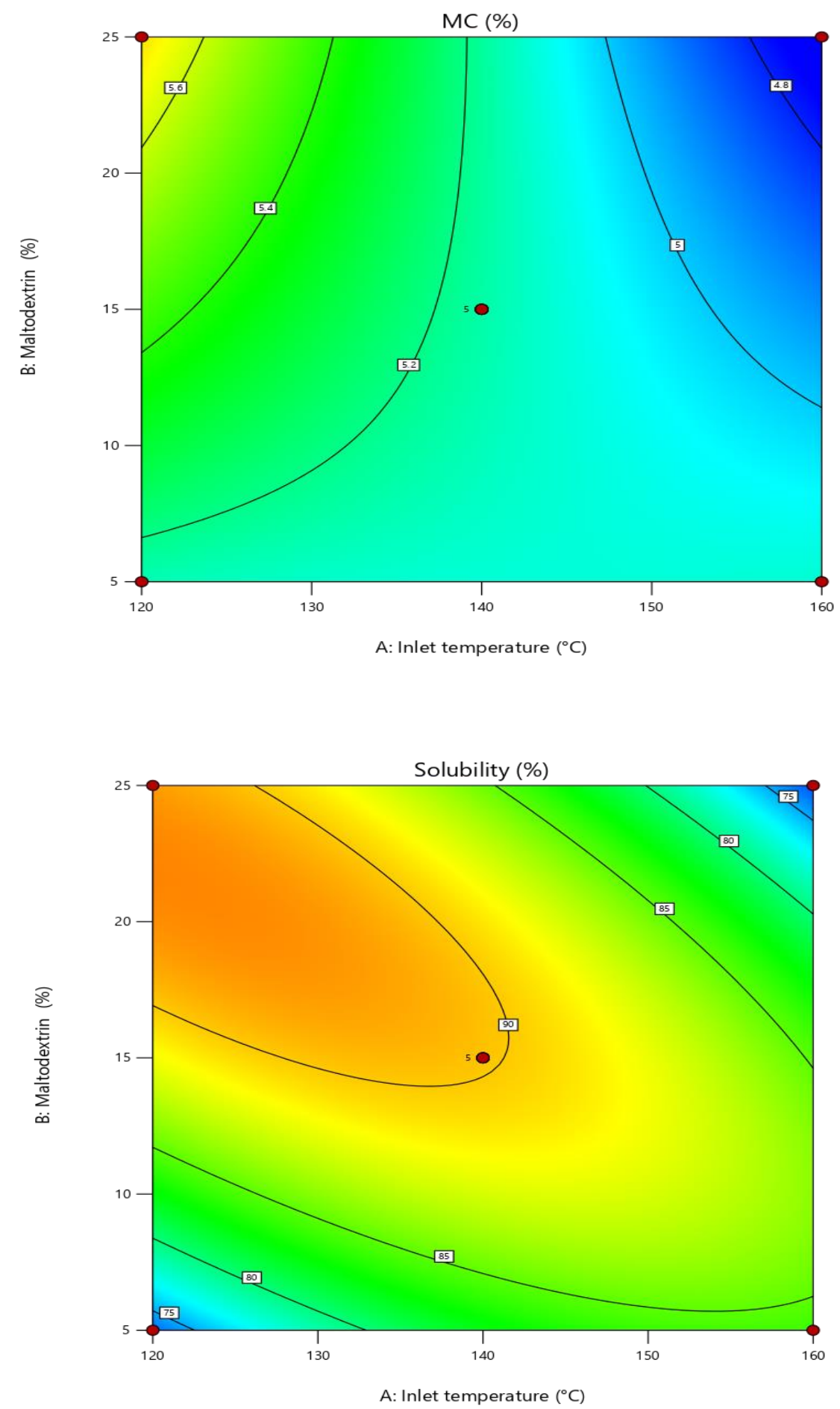

(B) 
Factor Coding: Actual

\section{Hygroscopicity (\%)}

Design Points

11

37.54

$\mathrm{X} 1=\mathrm{A}:$ Inlet temperature

$\mathrm{X} 2$ = B: Maltodextrin

(C)

Factor Coding: Actual

Whiteness index

Design Points

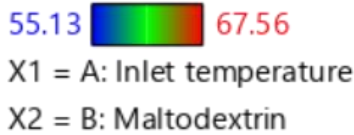

55.13

$\mathrm{X} 2=\mathrm{B}:$ Maltodextrin
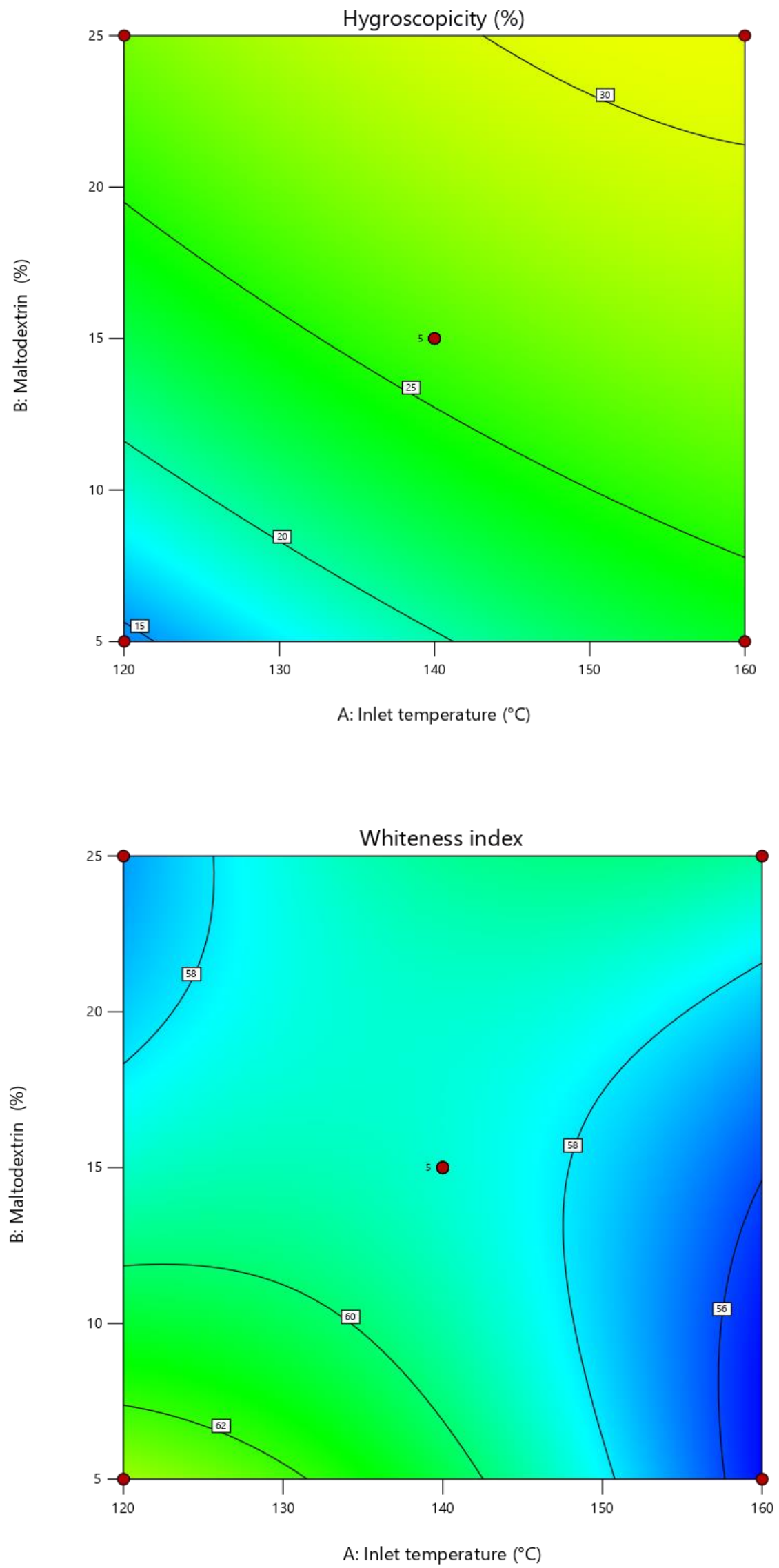

(D) 
Factor Coding: Actual

\section{Total sugar $(\mathbf{m g} / \mathrm{g})$}

Design Points

155.1

X1 = A: Inlet temperature $\mathrm{X} 2$ = B: Maltodextrin

(E)

Factor Coding: Actual

Soluble protein $\mathbf{( m g / g )}$

Design Points

\subsection{7 105.58 \\ $\mathrm{X} 1$ = A: Inlet temperature $\mathrm{X} 2=\mathrm{B}:$ Maltodextrin}
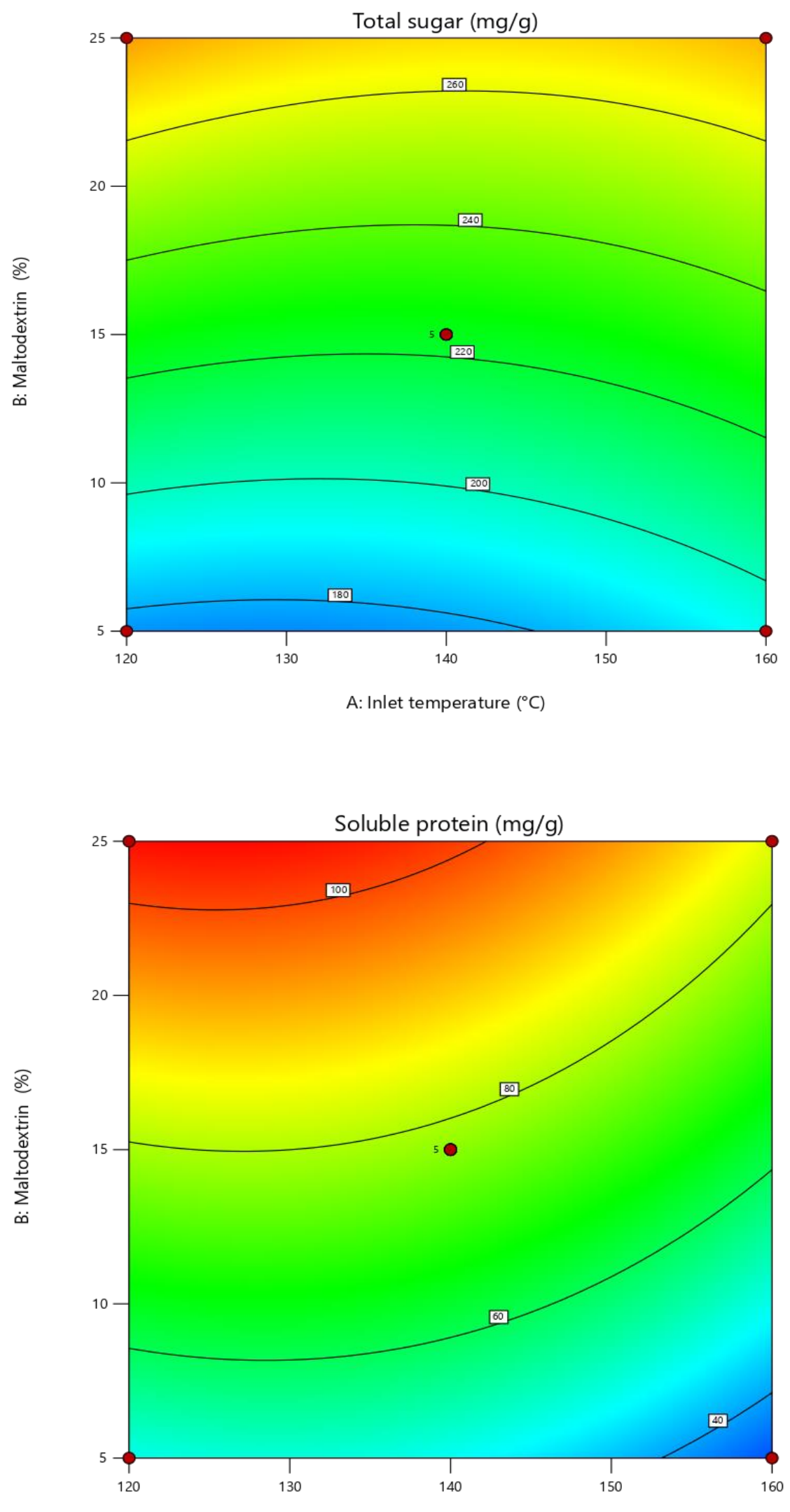

A: Inlet temperature $\left({ }^{\circ} \mathrm{C}\right)$

(F) 
Factor Coding: Actual

\section{Crude protein (\%)}

Design Points

29.75

$\mathrm{X} 1$ = A: Inlet temperature $\mathrm{X} 2=\mathrm{B}:$ Maltodextrin

\section{(G)}

\section{Factor Coding: Actual}

\section{Ash (\%)}

Design Points

3.2

$\mathrm{X} 1=\mathrm{A}:$ Inlet temperature $\mathrm{X} 2=\mathrm{B}:$ Maltodextrin

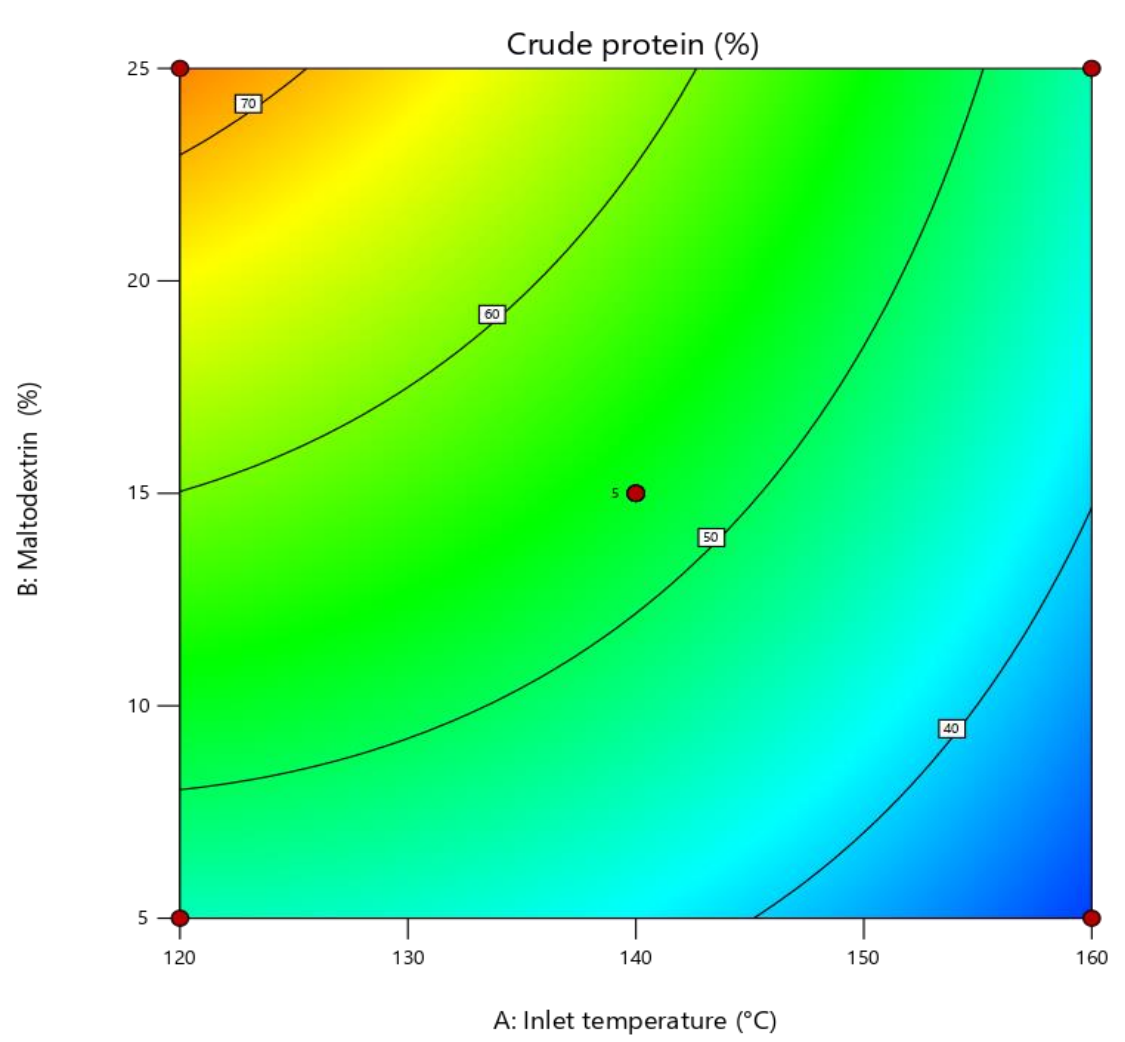

A: Inlet temperature $\left({ }^{\circ} \mathrm{C}\right)$

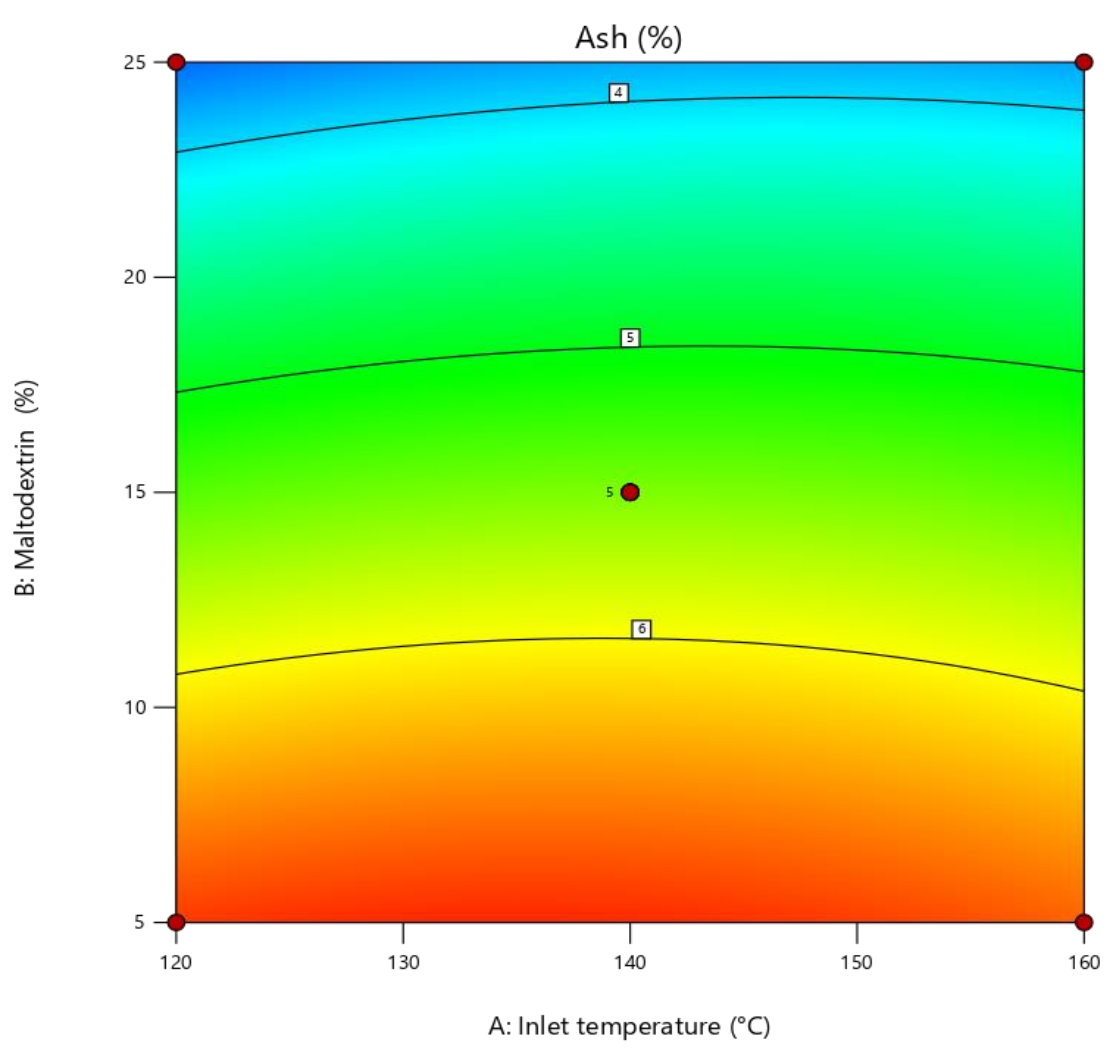

(H) 
Factor Coding: Actual

\section{TPC (mg GAE/g)}

Design Points

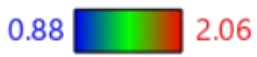

$\mathrm{X} 1=\mathrm{A}:$ Inlet temperature

$\mathrm{X} 2=\mathrm{B}:$ Maltodextrin

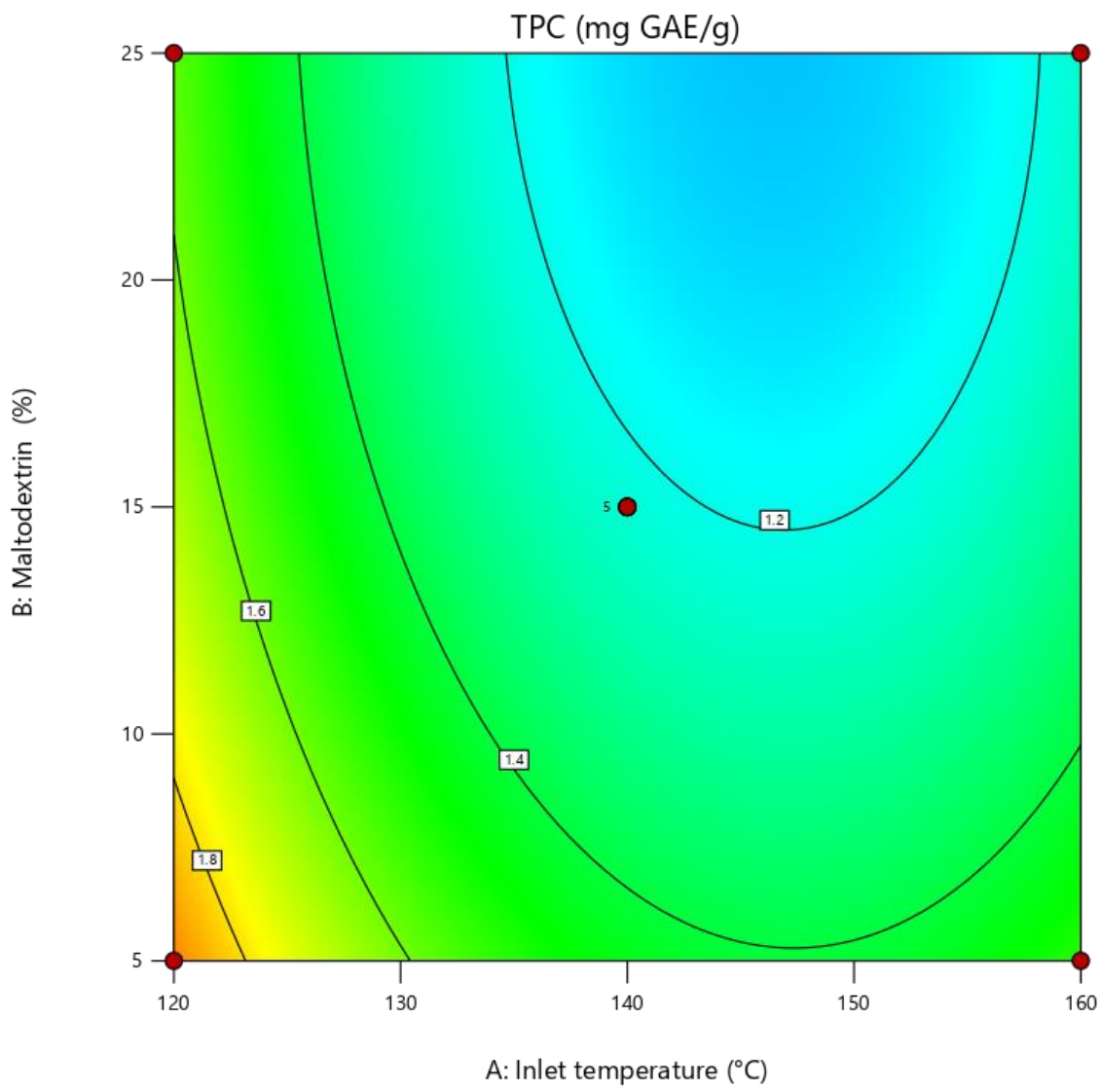

(I)

Figure S1. 2-D plot for (A) MC, (B) Solubility, (C) Hygroscopicity, (D) WI, (E) Total sugar, (F) Soluble protein, (G) Crude protein, (H) Ash content and (I) TPC.

All desiccated powders had some residual moisture, which was found to vary significantly $(\mathrm{p}<0.05)$ from $4.76 \%$ to $5.96 \%$. The lowest MC was recorded at inlet temperature of $160^{\circ} \mathrm{C}$ and $\mathrm{MD}$ concentration of $25 \%$. High inlet temperature ensures faster rate of moisture evaporation in the drying chamber and the high MD concentration aids the drying process by increasing the total solute in the feed, thereby, reducing the total moisture to be evaporated (Fazaeli, Emam-Djomeh, Kalbasi Ashtari, \& Omid, 2012).

All the spray dried samples were readily miscible in water at room temperature. Increasing inlet temperature and MD concentration significantly $(\mathrm{p}<0.05)$ increased the solubility of the spray dried powders. High inlet temperatures usually lead to higher moisture gradient, which in turn increases the particles' solubility (Cao et al., 2020). Presence of simple sugars in MD might have contributed to the high solubility of the developed powders. The results were consistent with the findings reported by Saikia et al. (2015).

Hygroscopicity was found to increase with the increasing inlet temperature and MD concentration. Steep moisture gradient between the low MC particles and the surrounding air results in greater moisture absorption upon exposure (Manickavasagan et al., 2015). Moreover, presence of MD aided the hygroscopicity of powders, given the inherent hygroscopic nature of its sugars (Manickavasagan et al., 2015; Nishad, Selvan, Mir, \& Bosco, 2017).

WI of the reconstituted beverage ranged from 55.32 to $67.09(\mathrm{p}<0.05)$. Probable occurrence of browning (Maillard reaction compounds) and/or caramelization of sugars, especially at high temperatures might have caused a decreased WI. Some published articles also found an increase in WI with increasing MD concentration (MichalskaCiechanowska, Majerska, Brzezowska, Wojdyło, \& Figiel, 2020; Srinivas, Vinoda, \& Lingathoti, 2018), which is in congruence to the present investigation. Total soluble sugars of the powders were highly influenced by MD concentration $(\mathrm{p}<0.05)$, and the highest value was recorded in powder developed at $120^{\circ} \mathrm{C}$ inlet temperature and $25 \%$ MD. Increase in sugar content of the powders with increasing MD concentration, was invariably credited to the 
carbohydrates of MD. However, when compared to that of the feed (T6), soluble sugars of the powders reduced by $36.87 \%$ to $60.94 \%$. This could be explained by their interaction with phenols and proteins in presence of high temperature, thus making them insoluble/unavailable for estimation (Mitrović et al., 2019).

In terms of soluble protein content, powders recuperated under different spray drying conditions showed significant differences $(\mathrm{p}<0.05)$. It decreased by $44.66-85.60 \%$, as compared to that of feed. Highest soluble protein was found in powder dried at $140^{\circ} \mathrm{C}$ with $\mathrm{MD}$ concentration of $\sim 29 \%$. High amount of MD perhaps averted the thermal denaturation of protein by providing an insulating barrier around them (Wang \& Zhong, 2014). Concurrent to the soluble protein, crude protein level presented a decreasing trend with increasing inlet temperature; while an increase was noted with the rising MD concentration. The observed results can be justified similarly as for soluble protein (Wang \& Zhong, 2014). Crude protein of the powders decreased in the range of 2.4-50.62\%, when compared to that of feed. Ash content of the powders significantly $(\mathrm{p}<0.05)$ decreased with increasing MD, probably because of the dilution of minerals in the feed by high amount of MD. Inlet temperature however, did not present any specific trend on the mineral content. Similar results were found by Siacor et al. (2020) while spray drying mango extracts. It is worth mentioning here that TPC of the feed was $11.45 \pm 0.66 \mathrm{~g}$ GAE/ $100 \mathrm{~g}$, which reduced by $58.88 \%$ as compared to that of fresh juice (Supplementary Table S9) and in the powders, it decreased by 98.20-99.23\%, as compared to that of feed. Plausible reason for this reduction may be the interaction of whey protein with the juice phenols (Zhang et al., 2013). Table 4 depicts the decrease in TPC of the developed powders with increasing inlet temperature and MD concentration, which can be ascribed to their thermal degradation and increasing thickness of the carrier material (MD), leading to lesser retention of polyphenols in the particle (Siacor et al., 2020). Similar trend was observed for TFC. Maximum TFC was observed in the sample sprayed at $120^{\circ} \mathrm{C}$ and $5 \% \mathrm{MD}$, whilst the minimum value was recorded at $140^{\circ} \mathrm{C}$ and $29 \% \mathrm{MD}$. Nonetheless, no significant variation ( $\left.\mathrm{p}>0.05\right)$ was apparent along the different inlet temperature and MD concentration.

Bulk and tap densities of the spray dried powders were not affected by the varying inlet temperature and MD ( $p>0.05$ ). This observation corroborates with the findings of Goula and Adamopoulos (2008), who developed spray dried tomato powder. HR ranged within 1.24 to 1.50 , which classify the powders' nature to be moderate to highly cohesive. CI varied from $19.35 \%$ to $33.50 \%$, signifying that the powders possessed a fair to poor flowability. These postulations agree with the inference from SEM images.

\subsection{Particle Morphology}

SEM images of the spray dried particles revealed their diameters ranging from 2 to $30 \mu \mathrm{m}$. Particles formed at high inlet temperature $\left(140^{\circ} \mathrm{C}, 160^{\circ} \mathrm{C}\right.$ or $\left.168^{\circ} \mathrm{C}\right)$ appeared to have shrunk and wrinkled surfaces Figures 3 (A), (B), (C)). On the other hand, the powder formed from low concentration of MD (\%) featured fused and clumped appearance (Figure $3(\mathrm{~F})$ ). The latter could be due to cohesiveness among the entities formed with low MD, a phenomenon commonly observed in case of spray dried products (Molina, Kaialy, Chen, Commandeur, \& Nokhodchi, 2018) and is also explained earlier in dispersibility and hygroscopicity. Akin to our observation, Du et al. (2014) also stated that spray dried Persimmon powder produced with MD had smooth surface and spherical shape, and that produced with whey protein concentrate or egg albumin was more agglomerated and shriveled. Occurrence of hygroscopic simple sugars and organic acids in both Dillenia indica juice and whey might be the contributing factor to the surface instabilities like shrinkage, clumping and wrinkle formation in our samples (Shrestha, Ua-arak, Adhikari, Howes, \& Bhandari, 2007; Siemons, Politiek, Boom, Sman, \& Schutyser, 2020). Powder recuperated under optimum condition also showed shriveled and wrinkled morphology with size varying from 3 to $9 \mu \mathrm{m}$ Figure $3(\mathrm{G})$, which substantiates its intermediate cohesiveness and flowability Table 3. 
Table 4. Experimental values of the physicochemical properties of spray dried Dillenia indica and whey powder.

\begin{tabular}{|c|c|c|c|c|c|c|c|c|c|c|c|c|c|c|c|}
\hline $\begin{array}{c}\text { Inlet } \\
\text { temperature } \\
\left({ }^{\circ} \mathbf{C}\right)\end{array}$ & $\begin{array}{l}\text { MD } \\
(\%)\end{array}$ & $\begin{array}{l}\text { MC } \\
(\%)\end{array}$ & $\begin{array}{c}\text { Solubility } \\
\text { (\%) }\end{array}$ & $\begin{array}{l}\text { Hygroscopicity } \\
(\mathrm{g} / 100 \mathrm{~g})\end{array}$ & $\begin{array}{l}\text { Bulk Density } \\
(\mathrm{g} / \mathrm{ml})\end{array}$ & $\begin{array}{c}\text { Tap Density } \\
(\mathrm{g} / \mathrm{ml})\end{array}$ & HR & $\begin{array}{l}\text { CI } \\
(\%)\end{array}$ & WI & $\begin{array}{l}\text { Soluble } \\
\text { Protein } \\
(\mathrm{mg} / \mathrm{g})\end{array}$ & $\begin{array}{c}\text { Sugar } \\
(\mathrm{mg} / \mathrm{g})\end{array}$ & $\begin{array}{c}\text { Crude } \\
\text { protein }(\%)\end{array}$ & Ash (\%) & $\begin{array}{l}\text { TPC (mg } \\
\text { GAE/g) }\end{array}$ & $\begin{array}{c}\text { TFC (mg } \\
\text { QE/g) }\end{array}$ \\
\hline 120 & 5 & $5.25 \pm 0.08^{\mathrm{a}}$ & $75.33 \pm 1.53^{\mathrm{b}}$ & $15.70 \pm 0.15^{\mathrm{b}}$ & $0.38 \pm 0.07^{\mathrm{a}}$ & $0.50 \pm 0.15^{\mathrm{a}}$ & $1.30 \pm 0.10^{\mathrm{a}}$ & $23.08 \pm 0.31^{\mathrm{c}}$ & $67.56 \pm 0.46^{\mathrm{h}}$ & $36.64 \pm 0.27^{\mathrm{b}}$ & $184.86 \pm 1.03^{\mathrm{b}}$ & $57.75 \pm 0.29^{j}$ & $6.90 \pm 0.07^{\mathrm{d}}$ & $2.06 \pm 0.36^{\mathrm{d}}$ & $0.55 \pm 0.09^{\mathrm{a}}$ \\
\hline 160 & 5 & $5.01 \pm 0.14^{\mathrm{a}}$ & $80.67 \pm 2.52^{\mathrm{e}}$ & $28.80 \pm 0.32^{\mathrm{h}}$ & $0.30 \pm 0.11^{\mathrm{a}}$ & $0.43 \pm 0.06^{\mathrm{a}}$ & $1.43 \pm 0.16^{\mathrm{a}}$ & $30.30 \pm 0.14 \mathrm{~g}$ & $57.54 \pm 0.35^{\mathrm{e}}$ & $27.47 \pm 0.50^{\mathrm{a}}$ & $193.97 \pm 1.35^{\mathrm{c}}$ & $31.50 \pm 0.16^{\mathrm{b}}$ & $6.75 \pm 0.09^{\mathrm{d}}$ & $1.48 \pm 0.26^{\mathrm{bcd}}$ & $0.50 \pm 0.21^{\mathrm{a}}$ \\
\hline 120 & 25 & $5.96 \pm 0.21^{\mathrm{b}}$ & $94.67 \pm 3.06^{\mathrm{k}}$ & $20.00 \pm 0.45^{\mathrm{c}}$ & $0.38 \pm 0.15^{\mathrm{a}}$ & $0.53 \pm 0.14^{\mathrm{a}}$ & $1.37 \pm 0.35^{\mathrm{a}}$ & $26.92 \pm 0.34^{\mathrm{e}}$ & $55.81 \pm 0.29^{b}$ & $103.57 \pm 0.44 \mathrm{j}$ & $298.82 \pm 1.14^{\mathrm{m}}$ & $58.75 \pm 0.34^{\mathrm{m}}$ & $3.45 \pm 0.08^{\mathrm{a}}$ & $1.89 \pm 0.72^{\mathrm{cd}}$ & $0.54 \pm 0.03^{a}$ \\
\hline 160 & 25 & $4.76 \pm 0.05^{\mathrm{a}}$ & $71.00 \pm 2.65^{\mathrm{a}}$ & $27.19 \pm 0.62^{\mathrm{f}}$ & $0.26 \pm 0.05^{\mathrm{a}}$ & $0.38 \pm 0.25^{\mathrm{a}}$ & $1.50 \pm 0.28^{\mathrm{a}}$ & $33.50 \pm 0.12^{\mathrm{i}}$ & $56.19 \pm 0.64^{\mathrm{b}}$ & $88.65 \pm 0.07^{\mathrm{i}}$ & $287.69 \pm 0.42^{1}$ & $38.50 \pm 0.03^{c}$ & $3.66 \pm 0.14^{\mathrm{a}}$ & $1.36 \pm 0.22^{\mathrm{abc}}$ & $0.47 \pm 0.14^{\mathrm{a}}$ \\
\hline 111.72 & 15 & $5.35 \pm 0.11^{\mathrm{a}}$ & $82.00 \pm 1.00^{f}$ & $24.20 \pm 0.37^{\mathrm{d}}$ & $0.36 \pm 0.20^{\mathrm{a}}$ & $0.50 \pm 0.31^{\mathrm{a}}$ & $1.40 \pm 0.23^{\mathrm{a}}$ & $28.57 \pm 0.16^{f}$ & $56.27 \pm 0.94^{\text {bc }}$ & $83.66 \pm 0.09^{\mathrm{h}}$ & $216.43 \pm 0.82^{\mathrm{e}}$ & $49.00 \pm 0.11^{f}$ & $5.22 \pm 0.10^{\mathrm{b}}$ & $1.75 \pm 0.04^{\mathrm{bcd}}$ & $0.53 \pm 0.14^{\mathrm{a}}$ \\
\hline 168.28 & 15 & $4.91 \pm 0.42^{\mathrm{a}}$ & $84.33 \pm 0.58^{\mathrm{h}}$ & $26.70 \pm 0.18^{\mathrm{f}}$ & $0.31 \pm 0.09^{\mathrm{a}}$ & $0.43 \pm 0.27^{\mathrm{a}}$ & $1.39 \pm 0.27^{\mathrm{a}}$ & $28.13 \pm 0.17^{\mathrm{f}}$ & $55.13 \pm 0.49^{\mathrm{a}}$ & $50.81 \pm 0.48^{\mathrm{d}}$ & $236.78 \pm 0.16 \mathrm{j}$ & $40.25 \pm 0.35^{\mathrm{d}}$ & $5.26 \pm 0.08^{\mathrm{b}}$ & $1.49 \pm 0.18^{\mathrm{bcd}}$ & $0.50 \pm 0.03^{a}$ \\
\hline 140 & 0.86 & $5.11 \pm 0.19^{\mathrm{a}}$ & $76.67 \pm 1.15^{\mathrm{c}}$ & $11.00 \pm 0.41^{\mathrm{a}}$ & $0.42 \pm 0.05^{\mathrm{a}}$ & $0.63 \pm 0.21^{\mathrm{a}}$ & $1.50 \pm 0.09^{\mathrm{a}}$ & $33.33 \pm 0.21^{\mathrm{i}}$ & $57.57 \pm 0.43^{\mathrm{e}}$ & $45.04 \pm 0.15^{\mathrm{c}}$ & $155.10 \pm 0.18^{\mathrm{a}}$ & $29.75 \pm 0.06^{\mathrm{a}}$ & $6.93 \pm 0.18^{\mathrm{d}}$ & $1.55 \pm 0.31^{\mathrm{bcd}}$ & $0.52 \pm 0.04^{\mathrm{a}}$ \\
\hline 140 & 29.14 & $4.98 \pm 0.47^{\mathrm{a}}$ & $78.33 \pm 3.15^{\mathrm{d}}$ & $37.54 \pm 0.19^{j}$ & $0.31 \pm 0.19^{\mathrm{a}}$ & $0.45 \pm 0.09^{\mathrm{a}}$ & $1.45 \pm 0.16^{\mathrm{a}}$ & $31.25 \pm 0.27^{\mathrm{h}}$ & $63.95 \pm 0.81^{\mathrm{g}}$ & $105.58 \pm 0.49^{\mathrm{k}}$ & $264.78 \pm 0.36^{\mathrm{k}}$ & $56.50 \pm 0.27^{1}$ & $3.20 \pm 0.08^{\mathrm{a}}$ & $0.88 \pm 0.03^{\mathrm{a}}$ & $0.18 \pm 0.05^{\mathrm{a}}$ \\
\hline 140 & 15 & $5.21 \pm 0.28^{\mathrm{a}}$ & $83.33 \pm 2.52^{g}$ & $28.00 \pm 0.38^{g}$ & $0.31 \pm 0.23^{\mathrm{a}}$ & $0.45 \pm 0.19^{\mathrm{a}}$ & $1.45 \pm 0.31^{\mathrm{a}}$ & $31.25 \pm 0.28^{\mathrm{h}}$ & $57.28 \pm 0.51^{\mathrm{de}}$ & $77.97 \pm 0.14^{\mathrm{f}}$ & $212.83 \pm 0.31^{\mathrm{d}}$ & $54.25 \pm 0.33^{\mathrm{i}}$ & $5.58 \pm 0.10^{\mathrm{bc}}$ & $1.25 \pm 0.45^{\mathrm{ab}}$ & $0.43 \pm 0.11^{\mathrm{a}}$ \\
\hline 140 & 15 & $5.19 \pm 0.15^{\mathrm{a}}$ & $87.67 \pm 2.08^{\mathrm{i}}$ & $23.83 \pm 0.27^{\mathrm{d}}$ & $0.32 \pm 0.25^{\mathrm{a}}$ & $0.40 \pm 0.23^{\mathrm{a}}$ & $1.24 \pm 0.26^{\mathrm{a}}$ & $19.35 \pm 0.22^{\mathrm{a}}$ & $61.72 \pm 0.75^{\mathrm{f}}$ & $79.11 \pm 0.06^{g}$ & $224.68 \pm 0.58^{\mathrm{g}}$ & $45.50 \pm 0.31^{\mathrm{e}}$ & $5.18 \pm 0.08^{\mathrm{b}}$ & $1.21 \pm 0.20^{\mathrm{ab}}$ & $0.34 \pm 0.29^{\mathrm{a}}$ \\
\hline 140 & 15 & $5.22 \pm 0.36^{\mathrm{a}}$ & $93.00 \pm 2.00 \mathrm{j}$ & $24.00 \pm 0.12^{\mathrm{d}}$ & $0.34 \pm 0.14^{\mathrm{a}}$ & $0.45 \pm 0.08^{\mathrm{a}}$ & $1.32 \pm 0.17^{\mathrm{a}}$ & $24.14 \pm 0.19^{\mathrm{d}}$ & $56.82 \pm 0.40^{\text {cd }}$ & $75.47 \pm 0.40^{\mathrm{e}}$ & $233.88 \pm 1.16^{\mathrm{i}}$ & $52.50 \pm 0.24^{\mathrm{h}}$ & $5.47 \pm 0.08^{\mathrm{bc}}$ & $1.19 \pm 0.59^{\mathrm{ab}}$ & $0.36 \pm 0.05^{\mathrm{a}}$ \\
\hline 140 & 15 & $5.16 \pm 0.32^{\mathrm{a}}$ & $88.00 \pm 4.36^{\mathrm{i}}$ & $30.06 \pm 0.09^{\mathrm{i}}$ & $0.36 \pm 0.23^{\mathrm{a}}$ & $0.50 \pm 0.25^{\mathrm{a}}$ & $1.40 \pm 0.19^{\mathrm{a}}$ & $28.57 \pm 0.24^{\mathrm{f}}$ & $61.86 \pm 0.77^{\mathrm{f}}$ & $75.96 \pm 0.15^{\mathrm{e}}$ & $227.65 \pm 0.82^{\mathrm{h}}$ & $55.25 \pm 0.10^{\mathrm{k}}$ & $5.50 \pm 0.14^{\mathrm{bc}}$ & $1.24 \pm 0.35^{\mathrm{ab}}$ & $0.38 \pm 0.06^{\mathrm{a}}$ \\
\hline 140 & 15 & $5.13 \pm 0.09^{\mathrm{a}}$ & $92.67 \pm 3.21^{\mathrm{j}}$ & $25.20 \pm 0.19^{\mathrm{e}}$ & $0.36 \pm 0.26^{\mathrm{a}}$ & $0.45 \pm 0.28^{\mathrm{a}}$ & $1.27 \pm 0.21^{\mathrm{a}}$ & $21.43 \pm 0.31^{\mathrm{b}}$ & $56.06 \pm 0.17^{\mathrm{b}}$ & $78.01 \pm 0.21^{f}$ & $218.02 \pm 0.83^{f}$ & $51.05 \pm 0.32^{g}$ & $5.89 \pm 0.07^{\mathrm{c}}$ & $1.23 \pm 0.32^{\mathrm{ab}}$ & $0.38 \pm 0.03^{\mathrm{a}}$ \\
\hline
\end{tabular}

Note: Value $=$ Mean $\pm \mathrm{SD}(\mathrm{N}=3)$; ${ }^{\mathrm{a}-\mathrm{m}}$ Means in the column with different letters are significantly different $(\mathrm{p}<0.05)$ 


\subsection{In-Vitro Digestion}

Digesta obtained from simulated gastric and intestinal digestion phases of T6 blend and its powder were compared with those of fresh D. indica juice and concentrated whey. It is apparent from Figure 4(A) that the percent protein released from the optimized powder, T6 blend and concentrated whey were lesser than that of fresh juice, possibly due to the presence of $\beta$-lactoglobulin in them, which is reported to be resistant to gastric digestion (Fu, Abbott, \& Hatzos, 2002; Meena, Prasad, Khamrui, Mandal, \& Bhat, 2021). As anticipated, the liberated protein from all the samples was seen to increase with time towards the intestinal digestion. However, the percent release from the optimized powder and T6 in both the phases of digestion was lower when compared to concentrated whey. This observation could be backed by the probable complexation/interaction of proteins with polyphenols, leading to lower leaching (Francielli et al., 2020).
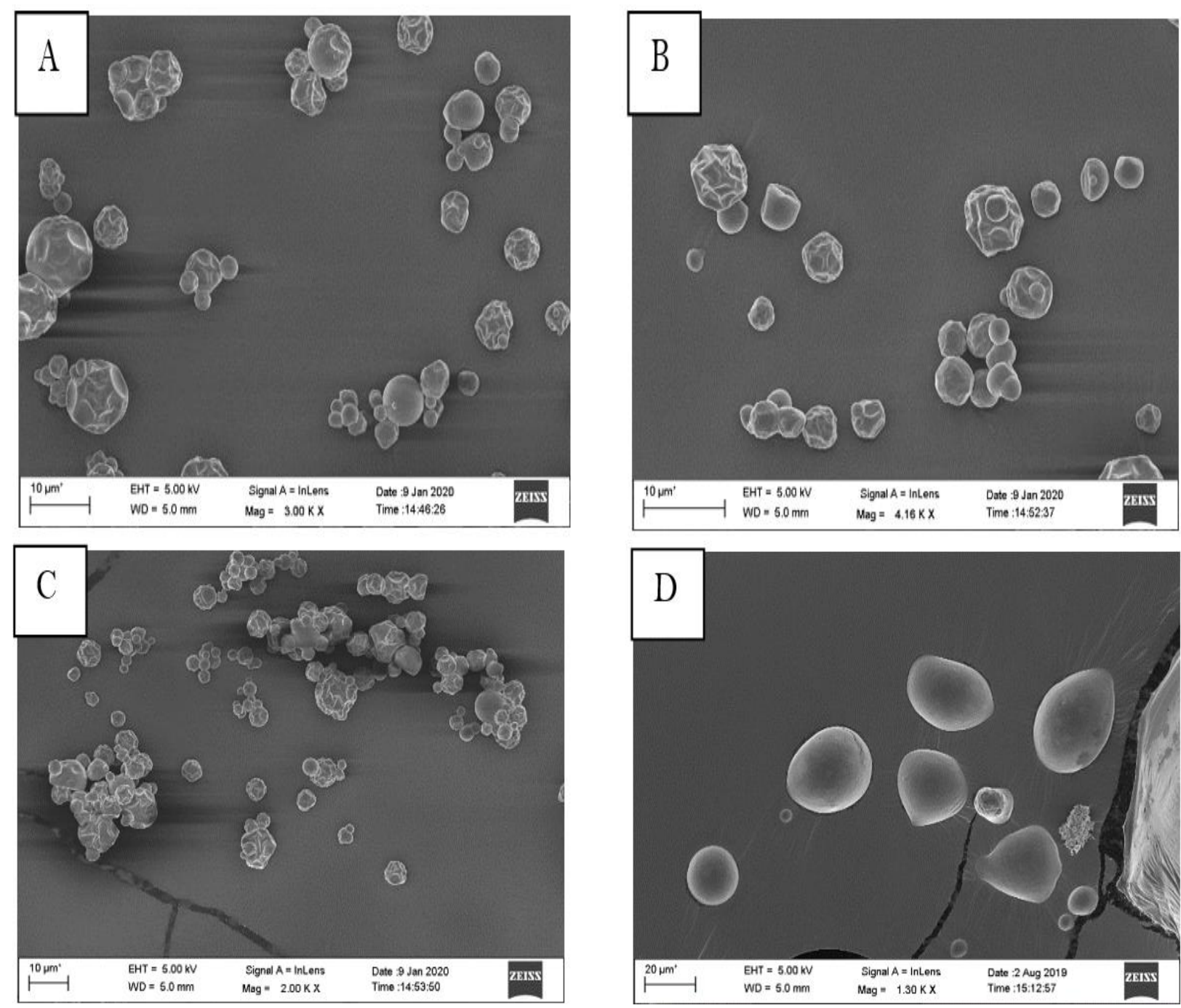

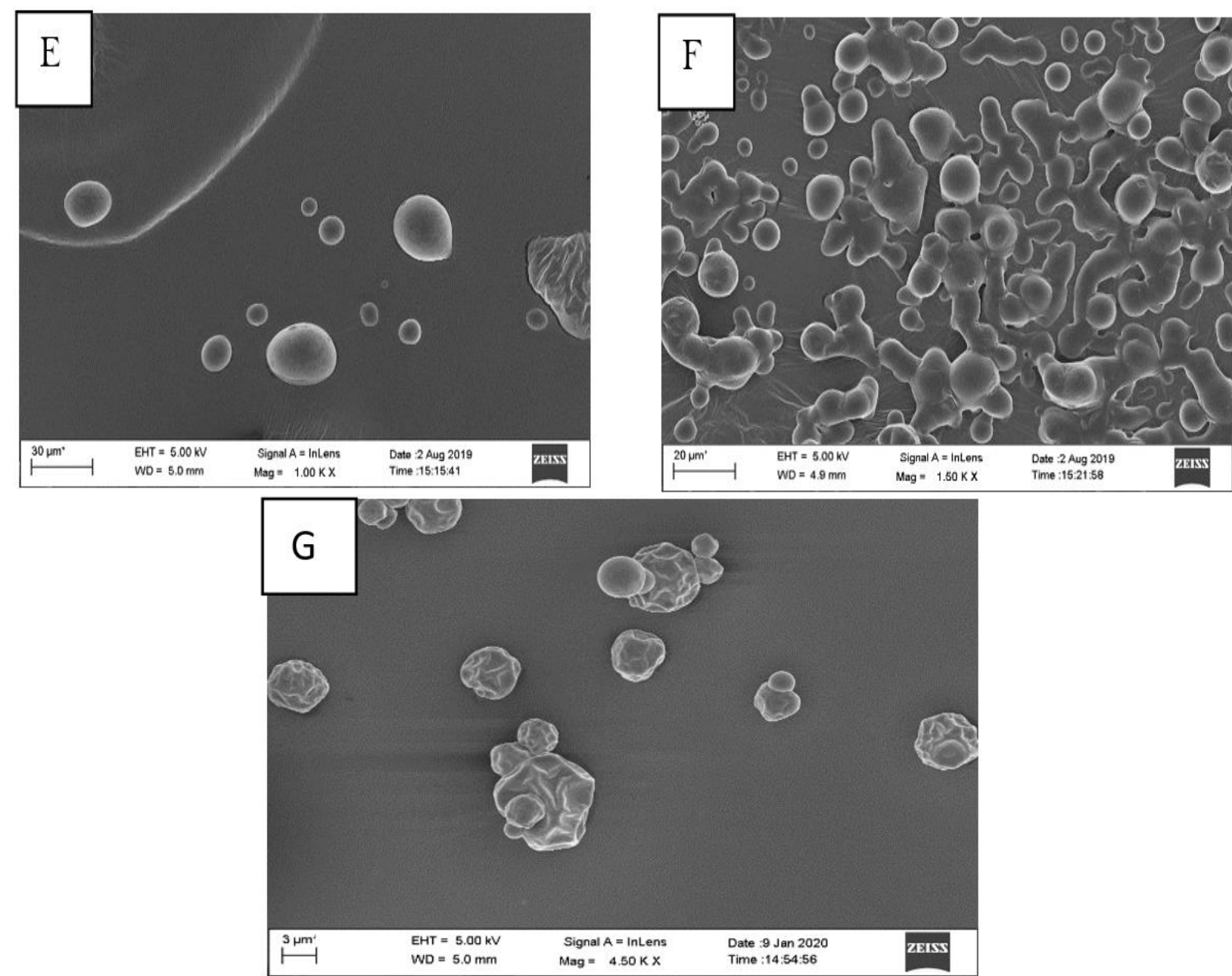

Figure 3. SEM images of beverage powder obtained at (A) $168^{\circ} \mathrm{C}$ and $15 \% \mathrm{MD}(\mathrm{B}) 140^{\circ} \mathrm{C}$ and $15 \% \mathrm{MD},(\mathrm{C}) 140^{\circ} \mathrm{C}$ and $29 \% \mathrm{MD},(\mathrm{D}) 111.7^{\circ} \mathrm{C}$ and $15 \% \mathrm{MD},(\mathrm{E}) 120^{\circ} \mathrm{C}$ and $25 \% \mathrm{MD},(\mathrm{F}) 140^{\circ} \mathrm{C}$ and $0.89 \% \mathrm{MD},(\mathrm{G}) 160{ }^{\circ} \mathrm{C}$ and $19.7 \% \mathrm{MD}$.

Furthermore, the antioxidant activity of the digesta obtained at different phases of gastrointestinal digestion is shown in Figure 4(B). The overall DPPH scavenging activity of the optimised powder, fresh juice, T6 blend, and whey, was lower after digestion than that prior to digestion $(\mathrm{p}<0.05)$. It reduced by $85 \%$ in the optimized powder and that of whey, T6 blend and fresh juice reduced by $72 \%, 90 \%$ and $95 \%$ respectively. Similar observation of drastic reduction in antioxidant activities after digestion is reported by numerous authors (Desseva \& Mihaylova, 2020; Mihaylova et al., 2021).

The polyphenols were partly stable under low $\mathrm{pH}$ of gastric period and hence were available for radical scavenging (Mihaylova et al., 2021). In the gastric phase, both the juice and T6 blend exhibited high antioxidant activity, while whey showed the lowest activity. It is interesting to mark that the antioxidant activity of whey digesta showed a persistent increase, which could be explained by the release of bioactive peptides under proteolytic condition (Francielli et al., 2020). Conversely, antioxidant features of the juice and blend started to decline with time in the intestinal phase. This observation could be explained by the sensitive nature of polyphenols under alkaline condition of the latter. Similar observation has been reported by Mihaylova et al. (2021). In case of the optimized powder, its scavenging activity seemed to increase during the digestion transit ( $>>0.05)$. Development of protective layers by drying adjunct as granular matter could illustrate the stability of polyphenols within the powder and the likely formation of active peptides from its constituent, can relate to its antioxidant potential. Lesser reduction of scavenging activity in optimized powder and T6 as compared to that of fresh juice again vouches the significance of whey and spray drying in preserving the bioactive ingredients against the harsh gut condition. 


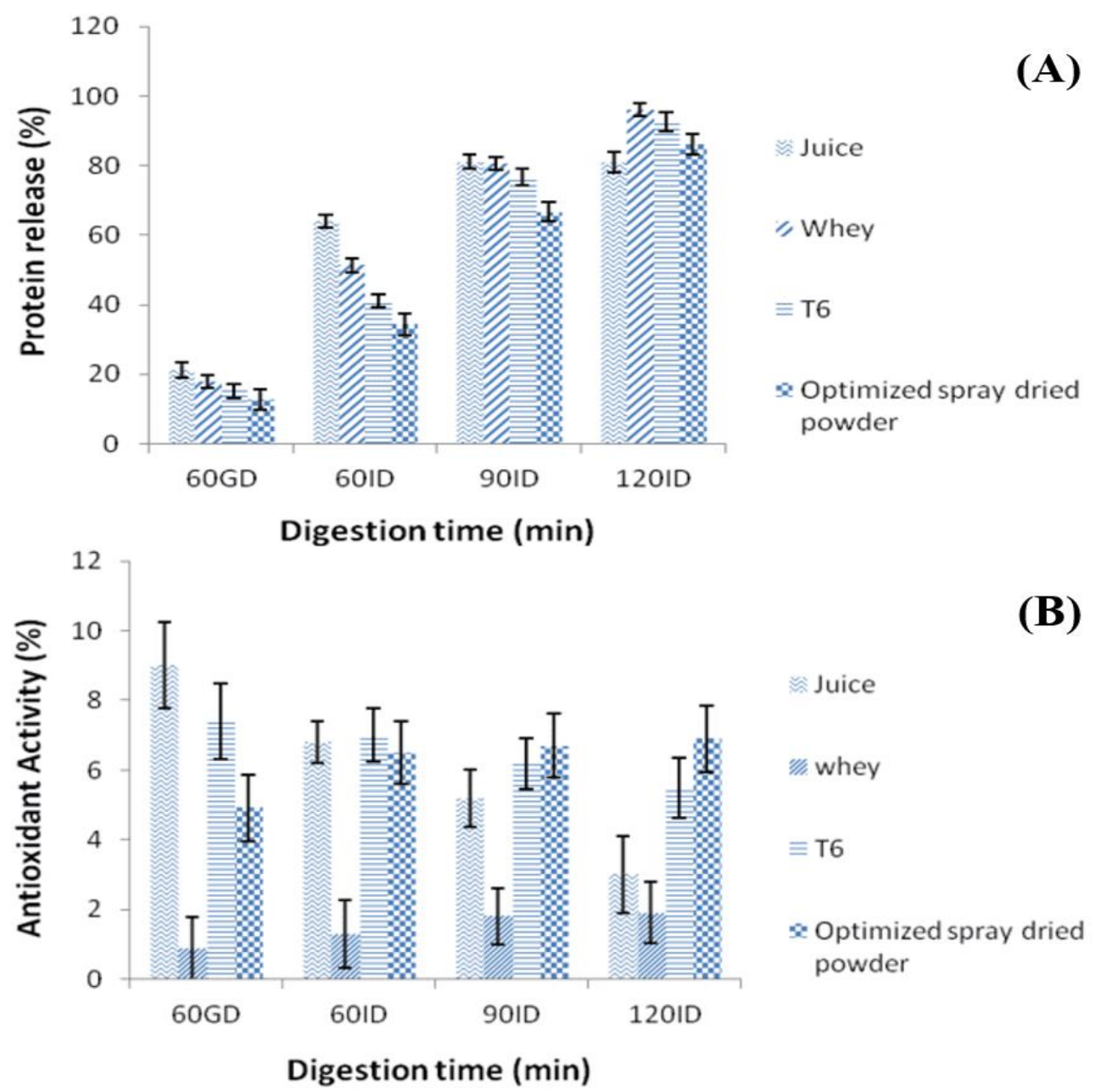

Figure 4. (A) Percent release of protein from Dillenia indica juice, concentrated whey, T6 blend and optimized powder during simulated Gastric digestion (GD) and Intestinal digestion (ID); (B) Antioxidant activity of Dillenia indica juice, T6 blend, concentrated whey and optimized powder during simulated Gastric digestion (GD) and Intestinal digestion (ID).

\section{CONCLUSION}

Results of the present investigation paved a novel methodology for processing an underutilized fruit using a protein-rich industrial byproduct (whey), into a beverage powder which could be reconstituted readily without compromising much on its antioxidant as-well-as techno-functional properties. Quadratic polynomial models derived for the responses (powders' yield, dispersibility, antioxidant activity and organoleptic acceptability) were found to be significant $(\mathrm{p} \leq 0.05)$ and adequate for prediction, which was validated by conducting confirmatory trials at the predicted optimum condition $\left(160^{\circ} \mathrm{C}\right.$ inlet temperature and $\left.19.727 \% \mathrm{MD}\right)$. Effect of the independent variables on additional quality parameters (MC, solubility, hygroscopicity, WI, Hausner and Carr indices, bulk and tap densities, total sugar, protein, minerals, phenols and flavonoids) of the powders were also assessed, wherein maximum retention of polyphenols, flavonoids and antioxidant activity was observed at $120^{\circ} \mathrm{C}$ inlet temperature and $5 \% \mathrm{MD}$, while the highest protein content was noticed at $140^{\circ} \mathrm{C}$ inlet temperature and $29 \% \mathrm{MD}$. Although the spray dried powders showed a drastic reduction in their phenolic content due to high temperature processing, nevertheless possible formation of antioxidative Maillard reaction products might have preserved the powders' antioxidant activity to a considerable extent. Moreover, the reconstituted beverage rendered better WI when compared to the fresh juice, indicating probable masking of the undesirable brown pigments by the amalgamation of whey and MD. Powder obtained under the optimized condition exhibited good solubility and dispersibility, intermediate hygroscopicity, fair flowability and retained high sugar, protein, WI and antioxidant potential when compared to the feed (T6). In vitro digestion of the optimized powder was compared to those of T6, fresh juice and concentrated whey. Lower release of 
soluble protein was witnessed in optimized powder in contrast to T6 and whey. Furthermore, the antioxidant activity of digesta from optimized powder showed a gradual increase with advancing phases of digestion $(\mathrm{p}<0.05)$, while those of fresh juice and T6 declined progressively due to probable degradation of polyphenols under alkaline intestinal environment. Therefore, the study proved that systematically optimized condition can help in creating a low-cost nutrient-dense beverage powder from an otherwise astringent minor fruit, without the addition of any exogenous sweetening agent.

Funding: This study received funding from Department of Biotechnology for Conducting Laboratory Experiments (Grant number: BT/PR16789/ NER/95/290/2015 dated March 14, 2017).

Competing Interests: The authors declare that they have no competing interests.

Authors' Contributions: All authors contributed equally to the conception and design of the study.

\section{REFERENCES}

Abdille, M. H., Singh, R. P., Jayaprakasha, G. K., \& Jena, B. S. (2005). Antioxidant activity of the extracts from Dillenia indica fruits. Food Chemistry, 90(4), 891-896.

Abraham, J., \& Mathew, F. (2013). Taste masking of pediatric formulation: A review on technologies, recent trends and regulatory aspects. International Journal of Pharmacy and Pharmaceutical Sciences, 6(1), 12-19.

Alayoubi, A., Daihom, B., Adhikari, H., Mishra, S., Helms, R., \& Almoazen, H. (2016). Development of a taste-masked oral suspension of clindamycin $\mathrm{HCl}$ using ion exchange resin Amberlite IRP 69 for use in pediatrics. Drug Development and Industrial Pharmacy, 42(10), 1579-1589.

Aliakbarian, B., Casazza, A., Nani, A., \& Perego, P. (2017). Production of chocolate powdered beverage with enhanced instant properties. Chemical Engineering Transactions, 57, 877-882.Available at: https://doi.org/10.3303/CET1757147.

AOAC. (2000). Official methods of analysis. Washington DC: Association of Official Analytical Chemists.

Bazaria, B., \& Kumar, P. (2016). Effect of whey protein concentrate as drying aid and drying parameters on physicochemical and functional properties of spray dried beetroot juice concentrate. Food Bioscience, 14, 21-27.Available at: https://doi.org/10.1016/j.fbio.2015.11.002.

Bernard, C., Regnault, S., Gendreau, S., Charbonneau, S., \& Relkin, P. (2011). Enhancement of emulsifying properties of whey proteins by controlling spray-drying parameters. Food Hydrocolloids, 25, 758-763.Available at: https://doi.org/10.1016/j.foodhyd.2010.08.011.

Bertelsen, A. S., Laursen, A., Knudsen, T. A., Møller, S., \& Kidmose, U. (2018). Bitter taste masking of enzyme-treated soy protein in water and bread. Journal of the Science of Food and Agriculture, 98, 3860-3869.Available at: https://doi.org/10.1002/jsfa.8903.

Bhusari, S. N., Muzaffar, K., \& Kumar, P. (2014). Effect of carrier agents on physical and microstructural properties of spray dried tamarind pulp powder. Powder Technology, 266, 354-364.Available at: https://doi.org/10.1016/j.powtec.2014.06.038.

Both, E. M., Boom, R. M., \& Schutyser, M. A. I. (2020). Particle morphology and powder properties during spray drying of maltodextrin and whey protein mixtures. Powder Technology, 363, 519-524.Available at: https://doi.org/10.1016/j.powtec.2020.01.001.

Cai, Y. Z., \& Corke, H. (2000). Production and properties of spray-dried amaranthus betacyanin pigments. Journal of Food Science, 65, 1248-1252.Available at: https://doi.org/10.1111/j.1365-2621.2000.tb10273.x.

Cao, C., Zhao, X., Zhang, C., Ding, Z., Sun, F., \& Zhao, C. (2020). Effect of inlet temperature on the physicochemical properties of spray-dried seed-watermelon seed protein powder. Journal of Food Science, 85, 3442-3449.Available at: https://doi.org/10.1111/1750-3841.15432.

Chau, C. F., Wang, Y. T., \& Wen, Y. L. (2007). Different micronization methods significantly improve the functionality of carrot insoluble fibre. Food Chemistry, 100, 1402-1408.Available at: https://doi.org/10.1016/j.foodchem.2005.11.034. 
Chen, F. P., Li, B. S., \& Tang, C. H. (2015). Nanocomplexation between curcumin and soy protein Isolate: Influence on curcumin stability. Journal of Agriculture and Food Chemistry, 63, 3559-3569.Available at: https://doi.org/10.1021/acs.jafc.5bo0448.

Chen, F. P., Liu, L. L., \& Tang, C. H. (2020). Spray-drying microencapsulation of curcumin nanocomplexes with soy protein isolate: Encapsulation, water dispersion, bioaccessibility and bioactivities of curcumin. Food Hydrocolloids, 105, 1-10.Available at: https://doi.org/10.1016/j.foodhyd.2020.105821.

Dantas, D., Pasquali, M. A., Cavalcanti-Mata, M., Duarte, M. E., \& Lisboa, H. M. (2018). Influence of spray drying conditions on the properties of avocado powder drink. Food Chemistry, 266, 284-291.Available at: https://doi.org/10.1016/j.foodchem.2018.06.016.

Das Purkayastha, M., Kalita, D., Mahnot, K. R., Mahanta, C., Mandal, M., \& Chaudhuri, K. M. (2012). Effect of l-ascorbic acid addition on the quality attributes of micro-filtered coconut water stored at $4{ }^{\circ} \mathrm{C}$. Innovative Food Science E Emerging Technologies, 16, 69-79.Available at: https://doi.org/10.1016/j.ifset.2012.04.007.

Deshmukh, N., Okram, S., Angami, T., Rymbai, H., \& Jha, A. K. (2019). Elephant apple (Dillenia indica). In: Minor fruits: Nutraceutical Importance and Cultivation (pp. 409-420). Delhi, India: Jaya Publishing House.

Desseva, I., \& Mihaylova, D. (2020). Influence of in vitro gastrointestinal digestion on phytochemicals in pomegranate juice. Food Science and Technology, 40, 211-216.Available at: https://doi.org/10.1590/fst.07219.

Du, J., Ge, Z. Z., Xu, Z., Zou, B., Zhang, Y., \& Li, C. M. (2014). Comparison of the efficiency of five different drying carriers on the spray drying of persimmon pulp powders. Drying Technology, 32, 1157-1166.Available at: https://doi.org/10.1080/07373937.2014.886259.

Fazaeli, M., Emam-Djomeh, Z., Kalbasi Ashtari, A., \& Omid, M. (2012). Effect of spray drying conditions and feed composition on the physical properties of black mulberry juice powder. Food and Bioproducts Processing, 90, 667-675.Available at: https://doi.org/10.1016/j.fbp.2012.04.006.

Francielli, P. R. M., Tássia, B. P., Eliseu, R., Luana, P. M., R.B.M., L., \& Flavia, M. N. (2020). Whey protein and phenolic compound complexation: Effects on antioxidant capacity before and after in vitro digestion. Food Research International, 133, 111.Available at: https://doi.org/10.1016/j.foodres.2020.109104.

Fu, T. J., Abbott, U. R., \& Hatzos, C. (2002). Digestibility of food allergens and nonallergenic proteins in simulated gastric fluid and simulated intestinal fluid a comparative study. Journal of Agriculture and Food Chemistry, 50, 7154-7160.Available at: https://doi.org/10.1021/jfo20599h.

Giri Saroj, K., Mangaraj, S., Sinha Lalan, K., \& Tripathi Manoj, K. (2017). Quality of spray dried soy beverage powder as affected by drying and feed parameters. Nutrition \& Food Science, 47, 567-577.Available at: https://doi.org/10.1 108/NFS-042016-0039.

Goula, A., \& Adamopoulos, K. (2008). Effect of maltodextrin addition during spray drying of tomato pulp in dehumidified air: I. drying kinetics and product recovery. Drying Technology, 26, 714-725.Available at: https://doi.org/10.1080/07373930802046369.

Jain, V., Karibasappa, G., Dodamani, A., \& Mali, G. (2017). Estimating the carbohydrate content of various forms of tobacco by phenol-sulfuric acid method. Journal of Education and Health Promotion, 6, 90-95.Available at: https://doi.org/10.4103/jehp.jehp_41_17.

Jinapong, N., Suphantharika, M., \& Jamnong, P. (2008). Production of instant soymilk powders by ultrafiltration, spray drying and fluidized bed agglomeration. Journal of Food Engineering, 84(2), 194-205.Available at: https://doi.org/10.1016/j.jfoodeng.2007.04.032.

Kamtekar, S., Keer, V., \& Patil, V. (2014). Estimation of phenolic content, flavonoid content, antioxidant and alpha amylase inhibitory activity of marketed polyherbal formulation. Journal of Applied Pharmaceutical Science, 4, 61-65.Available at: https://doi.org/10.7324/JAPS.2014.40911.

Lim, S. Y., Benner, L. C., \& Clark, S. (2019). Neither thermosonication nor cold sonication is better than pasteurization for milk shelf life. Journal of Dairy Science, 102, 3965-3977.Available at: https://doi.org/10.3168/jds.2018-15347. 
Manickavasagan, A., Kulandasamy, T., Dev, S., Delfiya, D., Nambi, E., Orsat, V., \& Raghavan, V. (2015). Physicochemical characteristics of date powder produced in a pilot scale spray dryer. Drying Technology, 33, 1-39.Available at: https://doi.org/10.1080/07373937.2015.1014045.

Meena, S., Prasad, W., Khamrui, K., Mandal, S., \& Bhat, S. (2021). Preparation of spray-dried curcumin microcapsules using a blend of whey protein with maltodextrin and gum arabica and its in-vitro digestibility evaluation. Food Bioscience, 41, 100990.Available at: https://doi.org/10.1016/j.fbio.2021.100990.

Michalska-Ciechanowska, A., Majerska, J., Brzezowska, J., Wojdyło, A., \& Figiel, A. (2020). The influence of maltodextrin and inulin on the physico-chemical properties of cranberry juice powders. Chemical Engineering, 4, 1-12.Available at: https://doi.org/10.3390/chemengineering4010012.

Migliato, K. F., Chiosini, M. A., Mendonca, F. A., Esquisatto, M. A., Salgado, H. R., \& Santos, G. M. (2011). Effect of glycolic extract of Dillenia indica L. combined with microcurrent stimulation on experimental lesions in wistar rats. Wounds: $A$ Compendium of Clinical Research and Practice, 23, 111-120.

Mihaylova, D., Desseva, I., Stoyanova, M., Petkova, N., Terzyiska, M., \& Lante, A. (2021). Impact of in vitro gastrointestinal digestion on the bioaccessibility of phytochemical compounds from eight fruit juices. Molecules, 26, 1-15.Available at: https://doi.org/10.3390/molecules26041187.

Mishra, P., Mishra, S., \& Mahanta, C. L. (2014). Effect of maltodextrin concentration and inlet temperature during spray drying on physicochemical and antioxidant properties of amla (Emblica officinalis) juice powder. Food and Bioproducts Processing, 92, 252-258.Available at: https://doi.org/10.1016/j.fbp.2013.08.003.

Mitrović, O., Popović, B., Miletic, N., Leposavić, A., \& Korićanac, A. (2019). Effect of drying on the change of sugar content in plum fruits (pp. 372-378). Jahorina, Bosnia \& Herzegovina: International Scientific Agriculture Symposium "Agrosym.

Molina, C., Kaialy, W., Chen, Q., Commandeur, D., \& Nokhodchi, A. (2018). Agglomerated novel spray-dried lactose-leucine tailored as a carrier to enhance the aerosolization performance of salbutamol sulfate from DPI formulations. Drug Delivery and Translational Research, 8, 1769-1780.Available at: https://doi.org/10.1007/s 13346-017-0462-8.

Mwove, J. K., Gogo, L. A., Chikamai, B. N., Omwamba, M., \& Mahungu, S. M. (2018). Principal component analysis of physicochemical and sensory characteristics of beef rounds extended with gum arabic from Acacia senegal var. kerensis. Food Science \& Nutrition, 6, 474-482.Available at: https://doi.org/10.1002/fsn3.576.

Nayak, P. K., Basumatary, B., Chandrasekar, C. M., Seth, D., \& Kesavan, R. K. (2020). Impact of thermosonication and pasteurization on total phenolic contents, total flavonoid contents, antioxidant activity, and vitamin C levels of elephant apple (Dillenia indica) juice. Journal of Food Process Engineering, 43, 1-11.Available at: https://doi.org/10.1111/jfpe.13447.

Nishad, J., Selvan, C. J., Mir, S. A., \& Bosco, S. J. D. (2017). Effect of spray drying on physical properties of sugarcane juice powder (Saccharum officinarum L.). Journal of Food Science and Technology, 54, 687-697.Available at: https://doi.org/10.1007/s13197-017-2507-x.

Pal, U. S., Khan, M. K., \& Mohanty, S. N. (2008). Heat pump drying of green sweet pepper. Drying Technology, 26, 15841590.Available at: https://doi.org/10.1080/07373930802467144.

Papadopoulou, A., \& Frazier, R. A. (2004). Characterization of protein-polyphenol interactions. Trends in Food Science $\bigotimes^{\circ}$ Technology, 15(3), 186-190.Available at: https://doi.org/10.1016/j.tifs.2003.09.017.

Park, C. W., Bastian, E., Farkas, B., \& Drake, M. (2014). The effect of acidification of liquid whey protein concentrate on the flavor of spray-dried powder. Journal of Dairy Science, 97(7), 4043-4051.Available at: https://doi.org/10.3168/jds.2013-7877.

Pathare, P. B., Opara, U. L., \& Al-Said, F. A. J. (2013). Colour measurement and analysis in fresh and processed foods: A review. Food and Bioprocess Technology, 6, 36-60.Available at: https://doi.org/10.1007/s1 1947-012-0867-9.

Puri, R., Khamrui, K., Khetra, Y., Malhotra, R., \& Devraja, H. C. (2016). Quantitative descriptive analysis and principal component analysis for sensory characterization of Indian milk product cham-cham. Journal of Food Science and Technology, 53, 12381246.Available at: https://doi.org/10.1007/s13197-015-2089-4. 
Saikia, A. (1999). Evaluation of some plant species as sources of natural food colorant. Docter of Philosophy, Assam Agricultural University, Jorhat.

Saikia, L., \& Saikia, J. (2002). Processing of Ou-Tenga (Dillenia indica) fruit for preparation of squash and its quality changes during storage. Journal of Food Science and Technology, 39(2), 149-151.

Saikia, S., Mahnot, N., \& Mahanta, C. (2015). Effect of spray drying of four fruit juices on physicochemical, phytochemical and antioxidant properties. Journal of Food Processing and Preservation, 39, 1656-1664.Available at: https://doi.org/10.1111/jfpp.12395.

Shi, Q., Fang, Z., \& Bhandari, B. (2013). Effect of addition of whey protein isolate on spray-drying behavior of Honey with Maltodextrin as a carrier material. Drying Technology, 31, 1681-1692.Available at: https://doi.org/10.1080/07373937.2013.783593.

Shrestha, A. K., Ua-arak, T., Adhikari, B. P., Howes, T., \& Bhandari, B. R. (2007). Glass transition behavior of spray dried orange juice powder measured by differential scanning calorimetry (DSC) and thermal mechanical compression test (TMCT). International Journal of Food Properties, 10(3), 661-673.

Siacor, F. D. C., Lim, K. J. A., Cabajar, A. A., Lobarbio, C. F. Y., Lacks, D. J., \& Taboada, E. B. (2020). Physicochemical properties of spray-dried mango phenolic compounds extracts. Journal of Agriculture and Food Research, 2, 1-8.Available at: https://doi.org/10.1016/j.jafr.2020.100048.

Sidlagatta, V., Venkata, C. S., Rao, D. B., Daniel, D. S., \& Lakshmipathy, R. (2020). Effect of maltodextrin concentration and inlet air temperature on properties of spray dried powder from reverse osmosis concentrated sweet orange juice. Brazilian Archives of Biology and Technology, 63, 1-14.Available at: https://doi.org/10.1590/1678-4324-2020190538.

Siemons, I., Politiek, R. G. A., Boom, R. M., Sman, R. G. M., \& Schutyser, M. A. I. (2020). Dextrose equivalence of maltodextrins determines particle morphology development during single sessile droplet drying. Food Research International, 131, 110.Available at: https://doi.org/10.1016/j.foodres.2020.108988.

Singleton, V. L., \& Rossi, J. A. (1965). Colorimetry of total phenolics with phosphomolybdic-phosphotungstic acid reagents. American Journal of Enology and Viticulture, 16(3), 144-158.

Soong, Y. Y., \& Barlow, P. J. (2004). Antioxidant activity and phenolic content of selected fruit seeds. Food Chemistry, 88, $411-$ 417.Available at: https://doi.org/10.1016/j.foodchem.2004.02.003.

Srinivas, D., Vinoda, N., \& Lingathoti, E. (2018). Effect of maltodextrin concentration on spray dried bitter gourd powder. International Journal of Current Microbiology and Applied Sciences, 7, 3147-3154.Available at: https://doi.org/10.20546/ijcmas.2018.705.368.

Sulieman, A. M. (2014). Comparison of physicochemical properties of spray-dried camel's milk and cow's milk powder. International Journal of Food Science and Nutrition Engineering, 4, 15-19.Available at: https://doi.org/10.5923/j.food.20140401.03.

Telang, A. M., \& Thorat, B. N. (2010). Optimization of process parameters for spray drying of fermented soy milk. Drying Technology, 28(12), 1445-1456.

Uscategui, D. C. R., Velásquez, H. J. C., \& Valencia, J. U. S. (2018). Concentrates of sugarcane juice and whey protein: Study of a new powder product obtained by spray drying of their combinations. Powder Technology, 333, 429-438.Available at: https://doi.org/10.1016/j.powtec.2018.04.025.

Vani, T., Rajani, M., Sarkar, S., \& Shishoo, C. J. (2008). Antioxidant properties of the ayurvedic formulation triphala and its constituents. Pharmaceutical Biology, 35, 313-317.Available at: https://doi.org/10.1080/09251619708951274.

Wang, B., Tchessalov, S., Warne, N. W., \& Pikal, M. J. (2009). Impact of sucrose level on storage stability of proteins in freezedried solids: I. Correlation of protein-sugar interaction with native structure preservation. Journal of Pharmaceutical Sciences, 3131-3144, 3131-3144.Available at: https://doi.org/10.1002/jps.21621.

Wang, W., \& Zhong, Q. (2014). Properties of whey protein-maltodextrin conjugates as impacted by powder acidity during the Maillard reaction. Food Hydrocolloids, 38, 85-94.Available at: https://doi.org/https://doi.org/10.1016/j.foodhyd.2013.11.018. 
Wang, W., Dufour, C., \& Zhou, W. (2015). Impacts of spray-drying conditions on the physicochemical properties of soy sauce powders using maltodextrin as auxiliary drying carrier. CyTA - Journal of Food, 13(4), 548-555.

Watson, M., Lea, J., \& Bett-Garber, K. (2017). Spray drying of pomegranate juice using maltodextrin/cyclodextrin blends as the wall material. Food Science Eீ Nutrition, 5, 820-826.Available at: https://doi.org/10.1002\%2Ffsn3.467.

Zhang, H., Yu, D., Sun, J., Guo, H., Ding, Q., Liu, R., \& Ren, F. (2013). Interaction of milk whey protein with common phenolic acids. Journal of Molecular Structure, 1058, 228-233.Available at: http://dx.doi.org/10.1016/j.molstruc.2013.11.009.

Views and opinions expressed in this article are the views and opinions of the author(s), Journal of Food Technology Research shall not be responsible or answerable for any loss, damage or liability etc. caused in relation to/arising out of the use of the content. 